University of Nebraska - Lincoln

DigitalCommons@University of Nebraska - Lincoln

Rapid Fluctuations in Mid-Latitude Siliceous Plankton Production during the Middle Eocene Climatic Optimum (ODP Site 1051, Western North Atlantic)

Jakub Witkowski

University of Szczecin, jakub.witkowski@univ.szczecin.pl

Steven M. Bohaty

University of Southampton, s.bohaty@noc.soton.ac.uk

Kirsty M. Edgar

Cardiff University

David M. Harwood

University of Nebraska-Lincoln, dharwood1@unl.edu

Follow this and additional works at: https://digitalcommons.unl.edu/andrillrespub

Part of the Climate Commons, Marine Biology Commons, Other Plant Sciences Commons, and the Paleobiology Commons

Witkowski, Jakub; Bohaty, Steven M.; Edgar, Kirsty M.; and Harwood, David M., "Rapid Fluctuations in Mid-Latitude Siliceous Plankton Production during the Middle Eocene Climatic Optimum (ODP Site 1051, Western North Atlantic)" (2014). ANDRILL Research and Publications. 58.

https://digitalcommons.unl.edu/andrillrespub/58

This Article is brought to you for free and open access by the Antarctic Drilling Program at DigitalCommons@University of Nebraska - Lincoln. It has been accepted for inclusion in ANDRILL Research and Publications by an authorized administrator of DigitalCommons@University of Nebraska Lincoln. 


\title{
Rapid fluctuations in mid-latitude siliceous plankton production during the Middle Eocene Climatic Optimum (ODP Site 1051, western North Atlantic)
}

\author{
Jakub Witkowski, ${ }^{1}$ Steven M. Bohaty, ${ }^{2}$ Kirsty M. Edgar, ${ }^{3}$ and David M. Harwood ${ }^{4}$ \\ 1. Geology and Palaeogeography Unit, Faculty of Earth Sciences, University of Szczecin, ul. Mickiewicza 18, 70-383 Szczecin, \\ Poland \\ 2. Ocean and Earth Science, University of Southampton, National Oceanography Centre, Southampton SO14 3ZH, UK \\ 3. School of Earth and Ocean Sciences, Cardiff University, Cardiff CF10 3AT, UK \\ 4. Department of Earth and Atmospheric Sciences, University of Nebraska-Lincoln, Lincoln, NE 68588-0340, USA \\ Corresponding author - Jakub Witkowski, email jakub.witkowski@univ.szczecin.pl
}

\begin{abstract}
The Middle Eocene Climatic Optimum (MECO; 40 million years ago [Ma]) is one of the most prominent transient global warming events in the Paleogene. Although the event is well documented in geochemical and isotopic proxy records at many locations, the marine biotic response to the MECO remains poorly constrained. We present new high-resolution, quantitative records of siliceous microplankton assemblages from the MECO interval of Ocean Drilling Program (ODP) Site 1051 in the subtropical western North Atlantic Ocean, which are interpreted in the context of published foraminiferal and bulk carbonate stable isotope $\left(\delta^{18} \mathrm{O}\right.$ and $\left.\delta^{13} \mathrm{C}\right)$ records. High diatom, radiolarian and silicoflagellate accumulation rates between 40.5 and $40.0 \mathrm{Ma}$ are interpreted to reflect an $\sim 500$ thousand year (kyr) interval of increased nutrient supply and resultant surface-water eutrophication that was associated with elevated sea-surface temperatures during the prolonged onset of the MECO. Relatively low pelagic siliceous phytoplankton sedimentation accompanied the peak MECO warming interval and the termination of the MECO during an $\sim 70 \mathrm{kyr}$ interval centered at $\sim 40.0 \mathrm{Ma}$. Following the termination of the MECO, an $\sim 200-\mathrm{kyr}$ episode of increased siliceous plankton abundance indicates enhanced nutrient levels between 39.9 and $39.7 \mathrm{Ma}$. Throughout the Site 1051 record, abundance and accumulation rate fluctuations in neritic diatom taxa are similar to the trends observed in pelagic taxa, implying either similar controls on diatom production in the neritic and pelagic zones of the western North Atlantic or fluctuations in sea level and/or shelf accommodation on the North American continental margin to the west of Site 1051. These results, combined with published records based on multiple proxies, indicate a geographically diverse pattern of surface ocean primary production changes across the MECO. Notably, however, increased biosiliceous accumulation is recorded at both ODP Sites 1051 and 748 (Southern Ocean) in response to MECO warming. This may suggest that increased biosiliceous sediment accumulation, if indeed a widespread phenomenon, resulted from higher continental silicate weathering rates and an increase in silicic acid supply to the oceans over several 100 kyr during the MECO.
\end{abstract}

Keywords: Eocene, North Atlantic, Blake Nose, Middle Eocene Climatic Optimum, Diatoms, Siliceous Microfossils, Ocean Drilling Program

\section{Introduction}

The Middle Eocene Climatic Optimum (MECO) is a global transient warming phase that occurred $\sim 40$ million years ago (Ma) (Bohaty and Zachos, 2003 and Bohaty et al., 2009) and temporarily reversed the long-term early-middle Eocene cooling trend (Zachos et al., 2001, Zachos et al., 2008 and Cramer et al., 2009) for 500-750 thousand years (kyr) (Bohaty et al., 2009 and Edgar et al., 2010). MECO warming is interpreted to have begun gradually in response to rising levels of atmospheric $\mathrm{CO}_{2}$ (Bijl et al., 2010). This phase of greenhouse warming terminated abruptly at $\sim 40 \mathrm{Ma}$, perhaps facilitated by enhanced organic carbon burial (Spofforth et al., 2010). High-latitude surfaceand deep-water warming of $\sim 4-6^{\circ}$ has been interpreted from foraminiferal stable isotope and organic geochemical proxies (Bohaty et al., 2009 and Bijl et al., 2010), and profound biotic changes have been documented in conjunction with MECO warming (e.g., Edgar et al., 2010, Edgar et al., 2013, Luciani et al., 2010, Toffanin et al., 2011, Witkowski et al., 2012 and Boscolo Galazzo et al., 2013). Recent modeling efforts (Sluijs et al., 2013) indicate that the MECO poses a major challenge to the established understanding of the carbon cycle variations operating on intermediate (100-500 kyr) timescales. Further insight into the nature of this prominent warming event will therefore improve our understanding of Paleogene ocean-atmosphere-biosphere interactions, as well as associated feedbacks that influenced climate change in the geological past. Of particular interest for 
mary production and carbon sequestration, which may provide clues, for example, to the mechanisms driving global temperature change during the event.

Siliceous microplankton are ubiquitous in marine environments and play a key role in marine primary production and carbon export. Several of the major siliceous groups, including diatoms and radiolarians, are characterized by an extensive fossil record and are widely used in paleoceanographic and paleoenvironmental reconstructions (e.g., Hollis et al., 1995, Stickley et al., 2008, Davies et al., 2009 and Jordan and Stickley, 2010). However, there are relatively few paleoceanographic studies of diatoms in Paleogene successions compared to other microfossil groups (e.g., foraminifera, dinoflagellates, calcareous nannofossils), mainly due to the sensitivity of the opaline frustules of diatoms to post-depositional diagenetic alteration. Yet, quantitative studies of diatoms from well-dated deep-sea successions are crucial for developing new productivity, temperature and salinity proxies for the Paleogene, and further development of high-resolution diatom assemblage records will aid in the refinement of biostratigraphic zonations. Given the importance of diatoms in primary production, elemental cycling, and carbon export and burial in the modern oceans (Ragueneau et al., 2000 and Tréguer and De La Rocha, 2013), an understanding of diatom response to past climate perturbations may also help to predict and model future changes in the climate-ocean system.

Drillcores recovered during Ocean Drilling Program (ODP) Leg 171B contain an expanded record of Paleogene climate variability (e.g., Bains et al., 1999 and Wade and Kroon, 2002), and a thick, middle Eocene section of siliceous nannofossil ooze spanning Chron C18, during which the MECO event occurred, was obtained at ODP Site 1051 (Shipboard Scientific Party, 1998a). The Site 1051 cores therefore provide an opportunity to apply existing diatom paleoecological tools to further elucidate paleoceanographic variability during the MECO (Bohaty et al., 2009 and Edgar et al., 2010), as well as refine siliceous microfossil paleoenvironmental proxies through comparison with foraminiferal datasets.

The specific goals of this study were to: (1) generate detailed siliceous microfossil assemblage records across an 2.6 million year (myr) interval spanning the MECO event; (2) interpret assemblage changes in the context of published foraminiferal and bulk carbonate stable isotope $\left(\delta^{13} \mathrm{C}, \delta^{18} \mathrm{O}\right)$ records and planktic foraminiferal assemblage records; (3) reconstruct the paleoenviron-

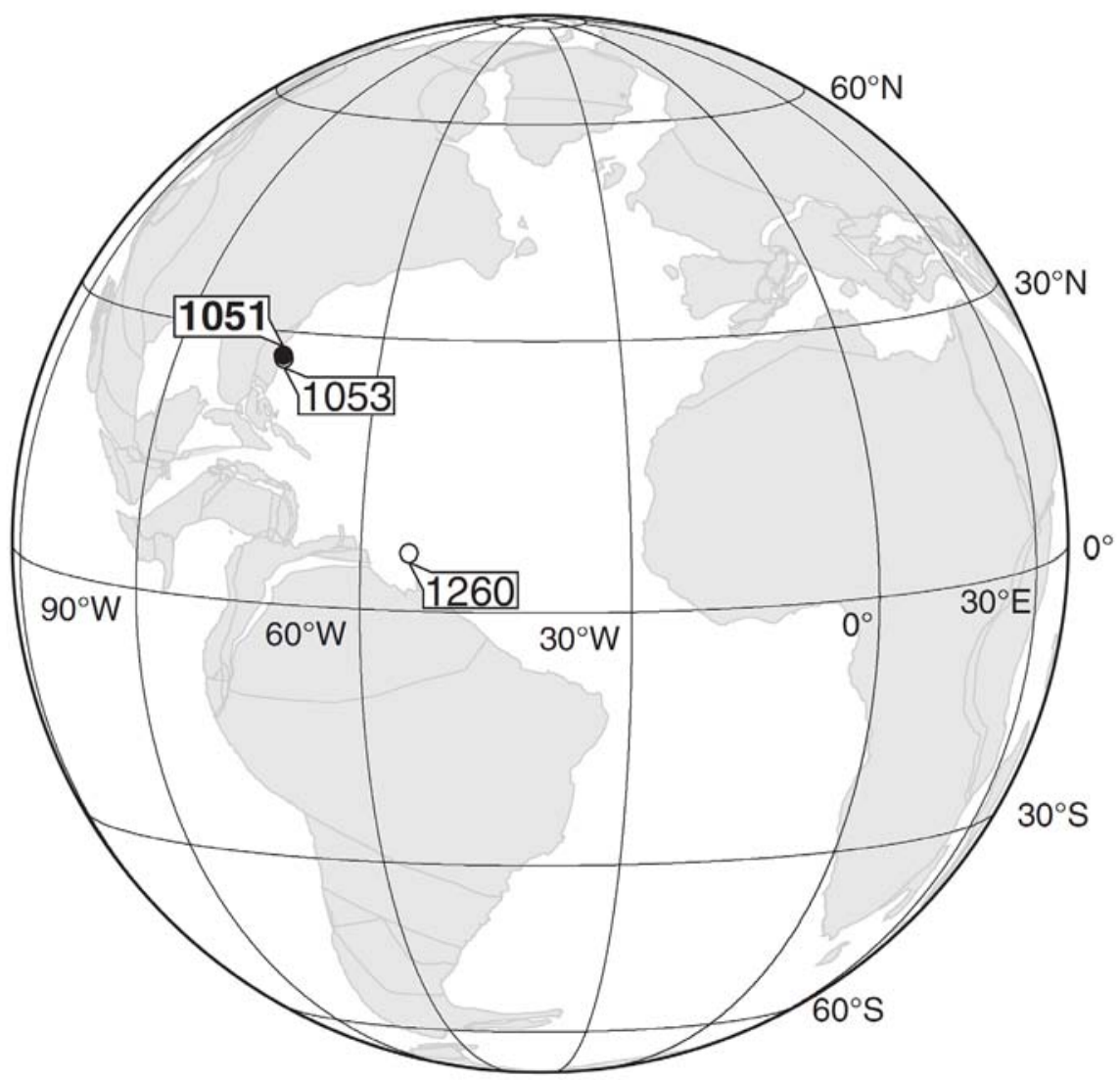

Figure 1. Paleogeographic map of the Atlantic Ocean at $40 \mathrm{Ma}$, showing the location of Site 1051 (closed circle) and other Atlantic ODP sites (open circles) referred to in this paper. Base map generated using Ocean Drilling Stratigraphic Network Plate Tectonic Reconstruction Service (www.odsn.de). 


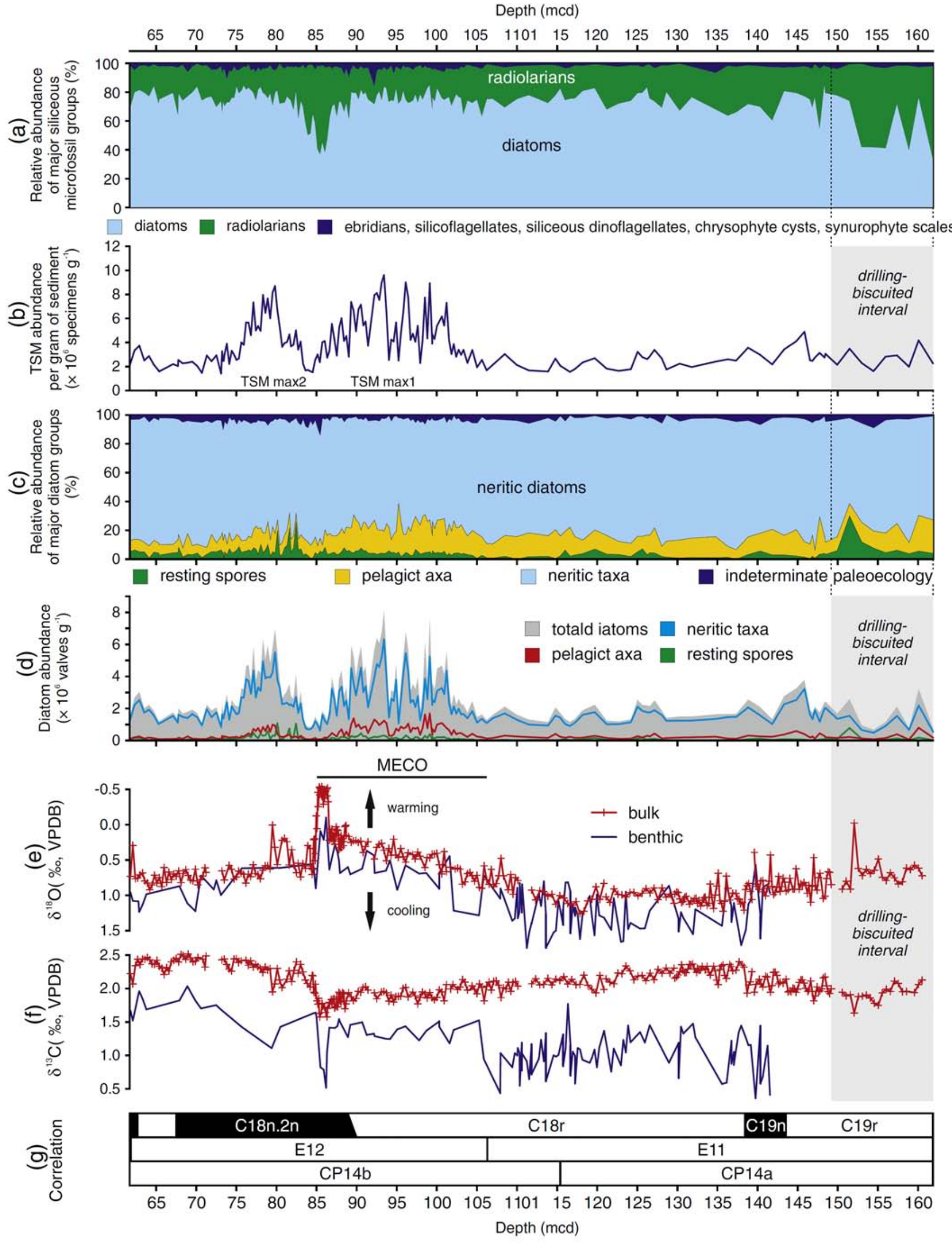


Table 1. Taxonomic list of diatoms identified in this study.

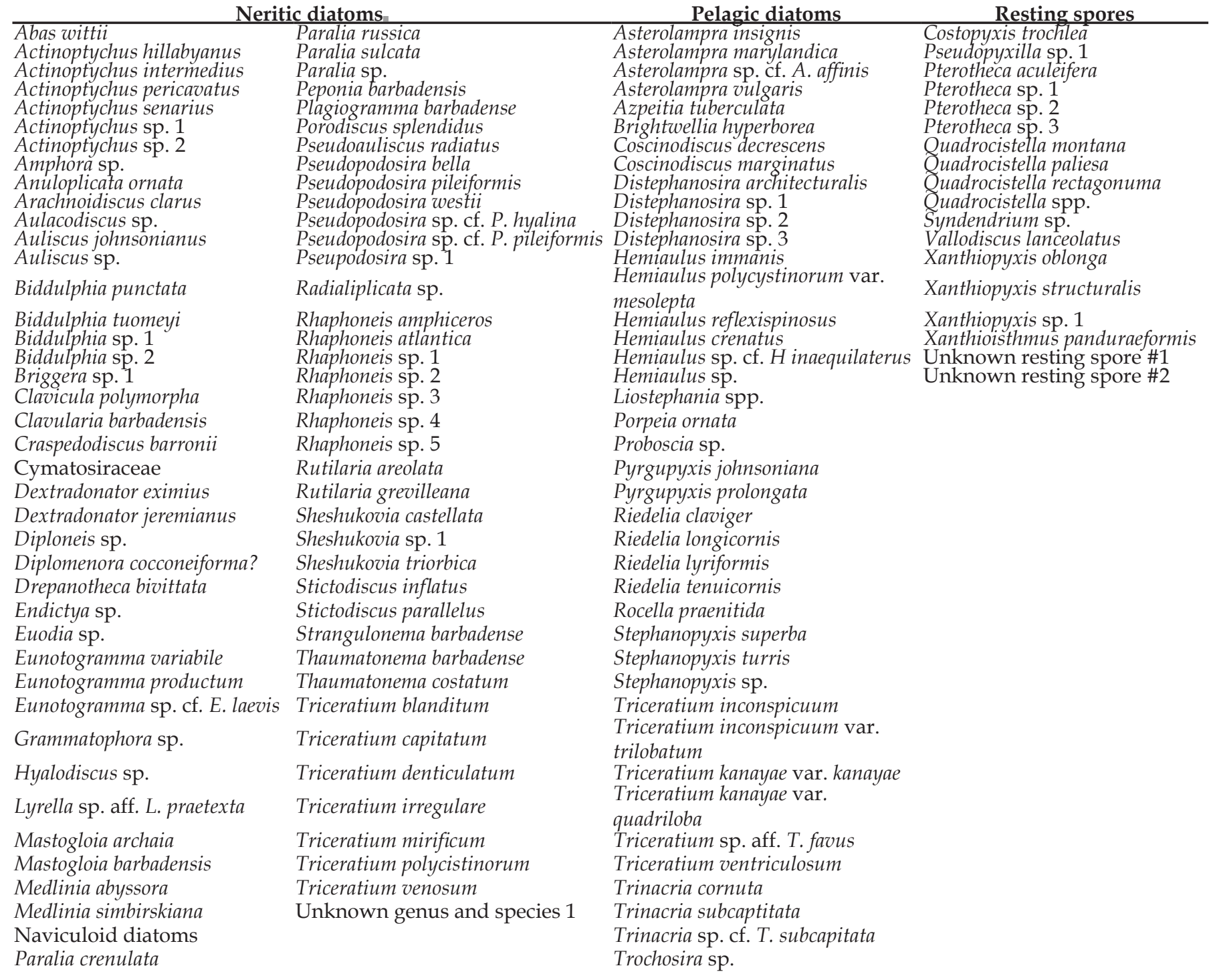

mental setting in which siliceous nannofossil ooze and chalk were deposited at Site 1051; and (4) use the siliceous microfossil data from Site 1051 to assess changes in subtropical siliceous plankton production in a regional and global context.

\section{Materials and methods}

\subsection{Geological setting and site location}

ODP Site $1051\left(30^{\circ} 03^{\prime} \mathrm{N}, 76^{\circ} 21^{\prime} \mathrm{W}\right)$ was drilled on Blake Nose, an eastward projection of the Blake Plateau, in the western subtropical North Atlantic Ocean (Fig. 1). Two holes (1051A and 1051B) were drilled at a water depth of $1980 \mathrm{~m}$ (Shipboard Scientific Party, 1998a). A 630-m thick Paleogene succession was recovered at Site 1051, including an 370-m thick middle Eocene interval characterized by high sedimentation rates $(\sim 4 \mathrm{~cm} / \mathrm{kyr})$ relative to many other pelagic deep-sea sections spanning this time interval (Edgar et al., 2010). A well-constrained magnetobiostratigraphic age model is available for the middle Eocene section of Site 1051 (Ogg and Bardot, 2001 and Edgar et al., 2010). The paleodepth for Site 1051 during the late Paleocene through middle Eocene time period is estimated at 1000-2000 m (Shipboard Scientific Party, 1998a).

Figure 2. Siliceous microfossil abundance records for ODP Site 1051: (a) relative abundance of major siliceous microfossil groups, (b) total siliceous microfossil (TSM) absolute abundance, (c) relative abundances of major diatom groups, and (d) diatom group absolute abundances, plotted with bulk and benthic $\delta 13 \mathrm{C}$ and $\delta 18 \mathrm{O}$ records (e-f). Correlation and/ or stable isotope data are from Mita (2001), Bohaty et al. (2009) and Edgar et al. (2010). Abbreviations: mcd-meters composite depth; TSM Max-total siliceous microfossil abundance maximum; VPDB-Vienna Pee Dee Belemnite. 
The middle Eocene interval recovered at Site 1051 between 161.9 and $61.7 \mathrm{~m}$ composite depth $(\mathrm{mcd})$ was selected for this study. Within this interval, the dominant lithology is siliceous nannofossil ooze, which grades downhole into siliceous nannofossil chalk at $\sim 148.5 \mathrm{mcd}$. With the exception of one poorly recovered core (Core 1051B-10H), drilling disturbance is generally minor within the advanced piston-cored (APC) oozedominated interval. However, the chalk-dominated interval below $\sim 148.5$ mcd was cored using the rotary extended core barrel (XCB) system and is moderately disturbed from the drilling process (Shipboard Scientific Party, 1998a; Fig. 2).

\subsection{Biostratigraphy and age model}

Although diatoms generally occur in high abundance in the upper middle Eocene section of Site 1051, the number of diatom bioevents is insufficient to provide reliable high-resolution age control. Instead, magnetostratigraphy combined with calcareous nannofossil and planktic foraminiferal biostratigraphy (Fig. 2g) provide the primary means of age control for the Eocene section of Site 1051 (Shipboard Scientific Party, 1998a, Mita, 2001, Ogg and Bardot, 2001 and Edgar et al., 2010). We utilize the magnetobiostratigraphic age model recently developed by Edgar et al. (2010), and, using this age model, our study interval spans an $\sim 2.6$ myr interval between 42.1 and 39.5 Ma. However, because of significant biscuiting of the sediment below $\sim 148.5$ mcd $(\sim 41.7 \mathrm{Ma})$, we focus our high-resolution analyses on the interval above this level (Fig. 2). In order to enable direct correlation of our results to other published records, all ages in this paper are reported relative to the timescale of Cande and Kent (1995), but additional age axes calibrated to the GTS2012 timescale (Gradstein et al., 2012) are also provided for reference in the relevant figures.

\subsection{Sample collection and processing}

In total, 175 samples from the shipboard splice of Holes 1051A and 1051B were examined for siliceous microfossils in this study (Shipboard Scientific Party, 1998a; Fig. S1c). An initial pilot study was performed at a stratigraphic resolution of $60-150 \mathrm{~cm}$, but the sampling interval was subsequently decreased to $10-30 \mathrm{~cm}$ spacing between 106.2 and $73.1 \mathrm{mcd}$ where the largest variations in siliceous microfossil assemblages were observed in the pilot results (Fig. 2b). Sample treatment methods and preparation of permanent slides followed Witkowski et al. (2012). The only modification to this methodology was that samples were not heated during $\mathrm{H}_{2} \mathrm{O}_{2}$ treatment because their low organic matter content enabled total digestion at room temperature.

Table 2. Taxonomic list of ebridians and silicoflagellates identified in this study.

\begin{tabular}{ll}
\multicolumn{1}{c}{ Ebridians } & \multicolumn{1}{c}{ Silicoflagellates } \\
\hline Ammodochium rectangulare & Corbisema angularis \\
Ammodochium speciosum & Corbisema bimucronata \\
Ebriopsis cornuta & Corbisema hexacantha \\
Ebriopsis crenulata & Corbisema spinosa \\
Ebriopsis sp. & Corbisema triacantha \\
'Falsebria' sp. & Dictyocha byronalis \\
Pseudoammodochium dictyoides & Naviculopsis sp.
\end{tabular}

Table 3. Taxonomic list of other siliceous microfossils indentified in this study.

\begin{tabular}{lll}
\multicolumn{1}{c}{ Dinoflagellates } & \multicolumn{1}{c}{ Incertae sedis } & Synurophyte scales \\
\hline $\begin{array}{l}\text { Actiniscus } \\
\text { pentasterias }\end{array}$ & $\begin{array}{l}\text { 'Naviculopsis hyalina } \\
\text { nordica' sensu } \\
\text { Ciesielski (1991) }\end{array}$ & Macrora barbadensis \\
Carduifolia gracilis & & Macrora stella
\end{tabular}

Peridinites

sphaericus

\subsection{Quantitative siliceous microfossil counts}

Siliceous microfossil counts were performed on two slides from each sample. At least three random traverses across the coverslip were made at $\times 1000$ magnification. For samples with low siliceous microfossil abundance, at least 100 siliceous microfossils were counted in multiple traverses. On average, $\sim 200$ siliceous microfossils were counted on each slide. Diatoms, silicoflagellates, ebridians, siliceous dinoflagellates and synurophyte

Plate I. Photomicrographs of key diatom taxa from the MECO interval of ODP Site 1051. All pairs represent high and low focus of the same specimen. Scale bar equals $20 \mu \mathrm{m}$, except for Figs. 8-10 and 17-18 (10 $\mu \mathrm{m})$, and Fig. 4 (15 $\mu \mathrm{m})$. Fig. 1a-b. Rhaphoneis atlantica, sample 171B-1050A-2H-5, 33-34 . Fig. 2. Diplomenora cocconeiforma?, sample 171B-1050A-2H-2, 33-34 cm. Fig. 3a-b. Mastogloia barbadensis, sample 171B-1051A-10H-2, 36-37 cm. Fig. 4. Mastogloia sp. aff. M. archaia, sample 171B-1051A-8H-4, 96-97 cm. Fig. 5. Lyrella sp. aff. L. praetexta, sample 171B-1051A-9H-3, 36-37 cm. Fig. 6. Strangulonema barbadense, sample 171B-1050A-2H-2, 33-34 cm. Fig. 7. Actinoptychus hillabyanus, sample 171B-1051B-12H-4, 6-7 cm. Fig. 8. Pseudopodosira bella, sample 171B-1051A-10H5, 66-67 cm. Fig. 9. Paralia sp., oblong specimen, sample 171B-1051B-9H-1, 96-97 cm. Fig. 10. Paralia crenulata, sample 171B-1051A-10H-5, 126$127 \mathrm{~cm}$. Fig. 11a-b. Abas wittii, sample 171B-1051A-8H-4, 126-127 cm. Fig. 12a-b. Hemiaulus immanis, sample 171B-1051A-8H-2, 6-7 cm. Fig. 13a-b. Hemiaulus polycystinorum var. mesolepta, sample 171B-1050A-2H-2, 33-34 cm. Fig. 14 . Triceratium inconspicuum var. inconspicuum, sample 171B-1051A-10H-4,36-37 cm. Fig. 15. Triceratium inconspicuum var. trilobata, sample 171B-1051B-15H-4, 4-5 cm. Fig. 16a-b. Coscinodiscus decrescens, sample171B-1051A-8H-2,96-97 cm. Figs.17-18. Distephanosira architecturalis, samples 171B-1051B12H-5, 6-7 cm (Fig. 17), 171B-1051A-10H5, 66-67 cm (Fig. 18). Fig. 19. Liostephania sp., sample 171B-1050A-2H-2, 33-34 cm. Fig. 20a-b. Rocella praenitida, sample 171B-1050A-3H-6, 33-34 cm. Fig. 21a-b. Xanthiopyxis oblonga, sample 171B-1051A-10H-1, 6-7 cm. Fig. 22ab. Quadrocistella montana, sample 171B-1051A-13H-5, 6-7 cm. Fig. 23a-b. Pterotheca aculeifera, sample 171B-1051A-19X-4, 126-127 cm. 
scales were identified to species level and counted following the method outlined by Schrader and Gersonde (1978). Radiolarians and chrysophyte cysts were also counted, but not identified. The technique for absolute siliceous microfossil abundance estimation follows the random settling method modification used by Witkowski et al. (2012). Range charts for all of the siliceous microfossil groups identified in this study are available in the online Supplementary materials section (Tables S1-S2). Taxonomic references are provided in Tables S3-S5.
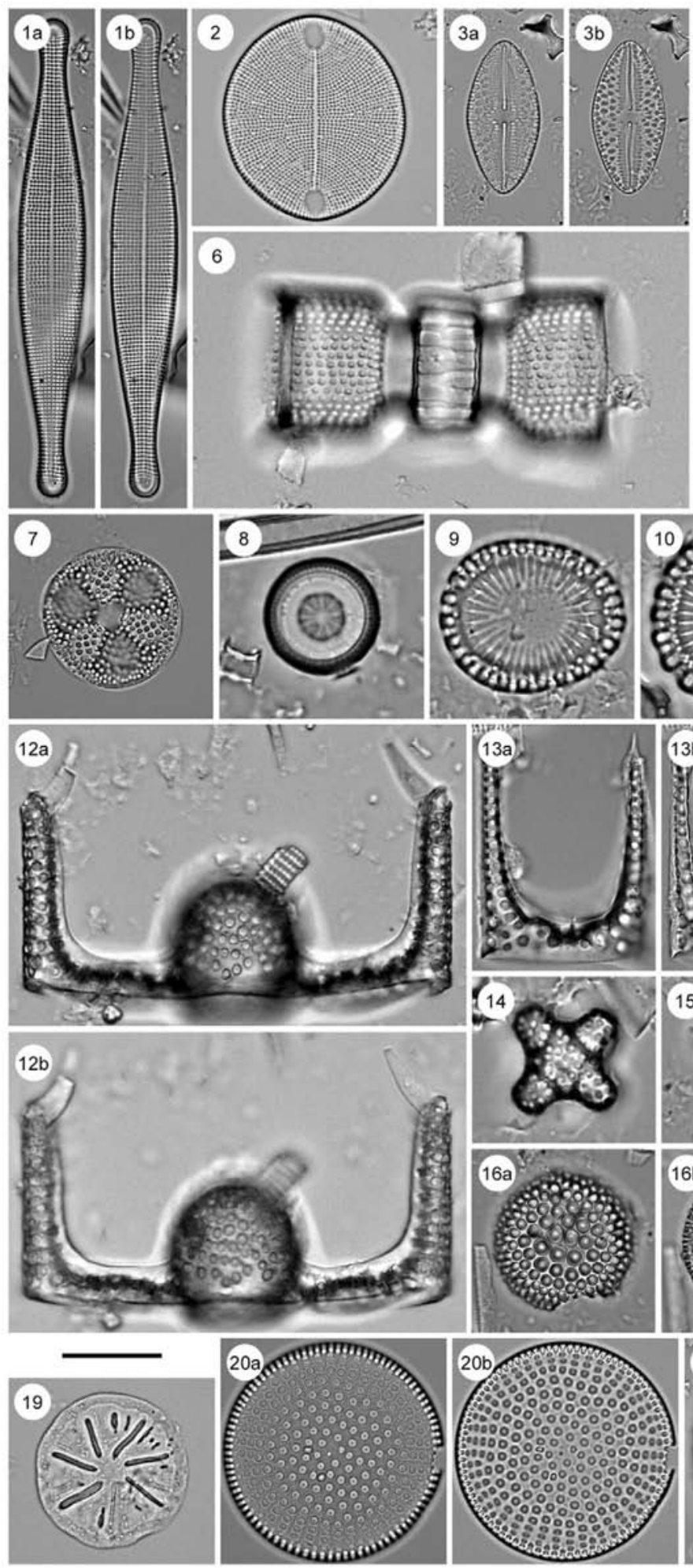
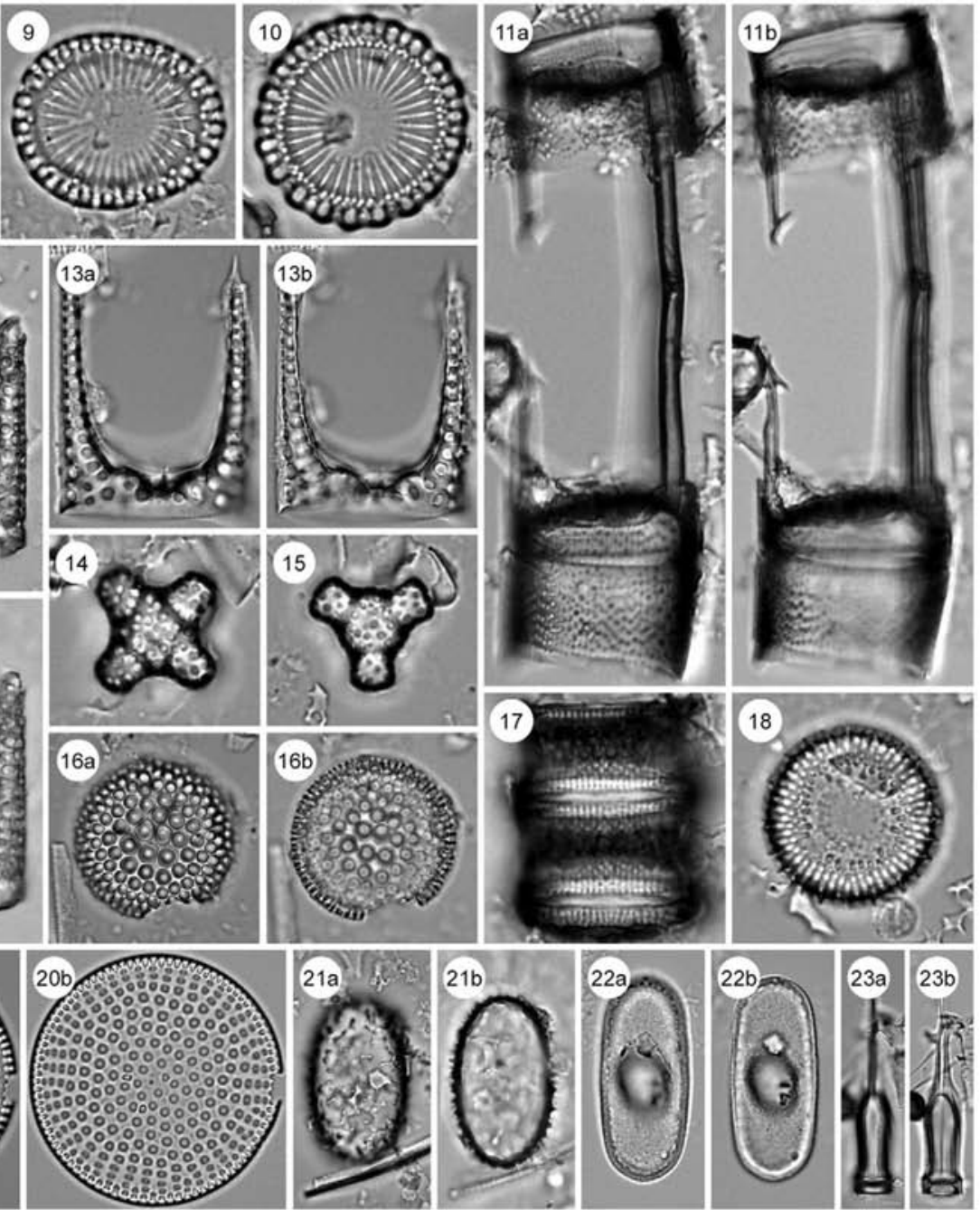


\subsection{Paleoecological assignments}

This study is based on both autotrophic and heterotrophic siliceous microplankton groups. Diatoms, silicoflagellates, synurophytes and chrysophytes are photosynthetic algal groups (Tappan, 1980, Andersen, 1987 and Round et al., 1990). The nutrition of the siliceous motile, thecate dinoflagellate Peridinites ( Harding and Lewis, 1994) is unknown, but fossil actiniscidians (e.g., Carduifolia) were likely naked, heterotrophic forms with internal spicular skeletons ( Preisig, 1994). Although radiolarians display several feeding strategies, they are generally considered heterotrophic (Matsuoka, 2007); both heterotrophic and mixotrophic behavior is reported for ebridians ( Witkowski et al., 2012).

Most of the diatom taxa recorded in this study are extinct, thus detailed paleoecological classification is challenging. To distinguish pelagic and neritic groups, we considered the global paleobiogeographic distribution of taxa, morphological features, and comparison to extant relatives, where applicable. Lists of diatom taxa and their inferred paleoecology are provided in Tables S3-S5 in the online Supplementary materials, and paleobiogeographic data from the published literature are compiled in Tables S6-S15.

\subsection{Sediment density and accumulation rate calcula- tions}

Accumulation rate estimates account both for changes in bulk sedimentation rate and dilution by other sedimentary components (biogenic and nonbiogenic), and thus provide a more accurate measure of changes in sedimentation through time than variations in the absolute abundance of microfossils. Sediment density and linear sedimentation rates (LSRs) are required to calculate sediment accumulation rates. In pelagic settings such as Site 1051 where silt and clay input is limited, variation in sediment density primarily reflects variations in the relative concentration of $\mathrm{CaCO}_{3}$ and $\mathrm{SiO}_{2}$, and thus can be used as an indirect proxy for biogenic opal concentration (Weber, 1998). In the Site 1051 study interval, high-resolution wet bulk density data, determined using the gamma ray attenuation porosity evaluator (GRAPE) method, correlate well with discrete dry bulk density (DBD) measurements made during routine shipboard analysis (Shipboard Scientific Party, 1998a). Therefore, it is possible to estimate DBD at high resolution by calibrating the GRAPE record with the discrete DBD data (Fig. S2). Total siliceous microfossil, diatom, silicoflagellate and radiolarian accumulation rates were calculated using these high-resolution DBD estimates and the LSRs derived from the Edgar et al. (2010) age model.

\subsection{Stable isotope records}

In order to explore the possible links between surface-ocean primary production and late middle Eocene greenhouse warming at Site 1051, siliceous microfossil assemblage changes are interpreted in the context of published stable isotope records $\left(\delta^{18} \mathrm{O}, \delta^{13} \mathrm{C}\right)$ (Bohaty et al., 2009 and Edgar et al., 2010). The abundance of benthic foraminifera is low within the MECO interval of Site 1051, hindering development of a high-resolution stable isotope stratigraphy (Edgar et al., 2010). However, a high-resolution bulk-sediment stable isotope record is available across our study interval (Bohaty et al., 2009; Fig. 2e-f), which provides a surface-water signal from calcareous nannofossils - the dominant sedimentary component of Eocene sediments at Site 1051 (Shipboard Scientific Party, 1998a). In comparison to planktic foraminiferal and fine-fraction stable isotope records in Miocene pelagic sediments, Ennyu et al. (2002) inferred that the fine-fraction (calcareous nannofossil) stable isotope records are strongly influenced by the season of calcification, and likely reflect blooms during periods of deep mixing in the late winter or early spring characterized by cool, high-nutrient conditions. Therefore, the bulk stable isotope signals at Site 1051 may be similarly biased towards cool conditions that are not representative of summer sea-surface temperatures. This may explain why, for instance, the bulk and benthic $\delta^{18} \mathrm{O}$ values overlap in some intervals of the Site 1051 study section (Fig. S1a), although vital-effect offsets or diagenetic alteration also cannot be ruled out. The trends and relative changes, however, are similar between the bulk $\delta^{18} \mathrm{O}$ record and the lower-resolution benthic foraminiferal $\delta^{18} \mathrm{O}$ record (Fig. $2 \mathrm{e}-\mathrm{f}$ ), providing parallel indications of relative temperature change.

\section{Results}

\subsection{Siliceous microfossil abundance}

Siliceous microfossils are present throughout the Site 1051 study interval, and a diverse range of siliceous microfossil groups was identified, including diatoms (average $\sim 73 \%$ of the total siliceous microfossil assemblage), radiolarians $(\sim 24 \%)$, ebridians $(\sim 0.8 \%)$, silicoflagellates $(\sim 0.1 \%)$, and chrysophyte cysts, siliceous dinoflagellates, and synurophyte scales $(\sim 2.1 \%$ of the assemblage combined) (Fig. 2a). Taxonomic lists of all siliceous microfossil taxa identified in this study are presented in Table 1, Table 2 and Table 3. The absolute total siliceous microfossil (TSM) abundance is relatively low $\left(\sim 2.6 \times 10^{6}\right.$ siliceous microfossils per gram of sediment $\left[\mathrm{g}^{-1}\right]$ on average) and shows little variability below the MECO between 148.5 and $106.2 \mathrm{mcd}$, and above the MECO interval between 73.2 and 61.7 mcd (Fig. 2b). A broad interval of elevated TSM abundance, with two maxima, is recorded between 106.2 and $73.2 \mathrm{mcd}$-here 


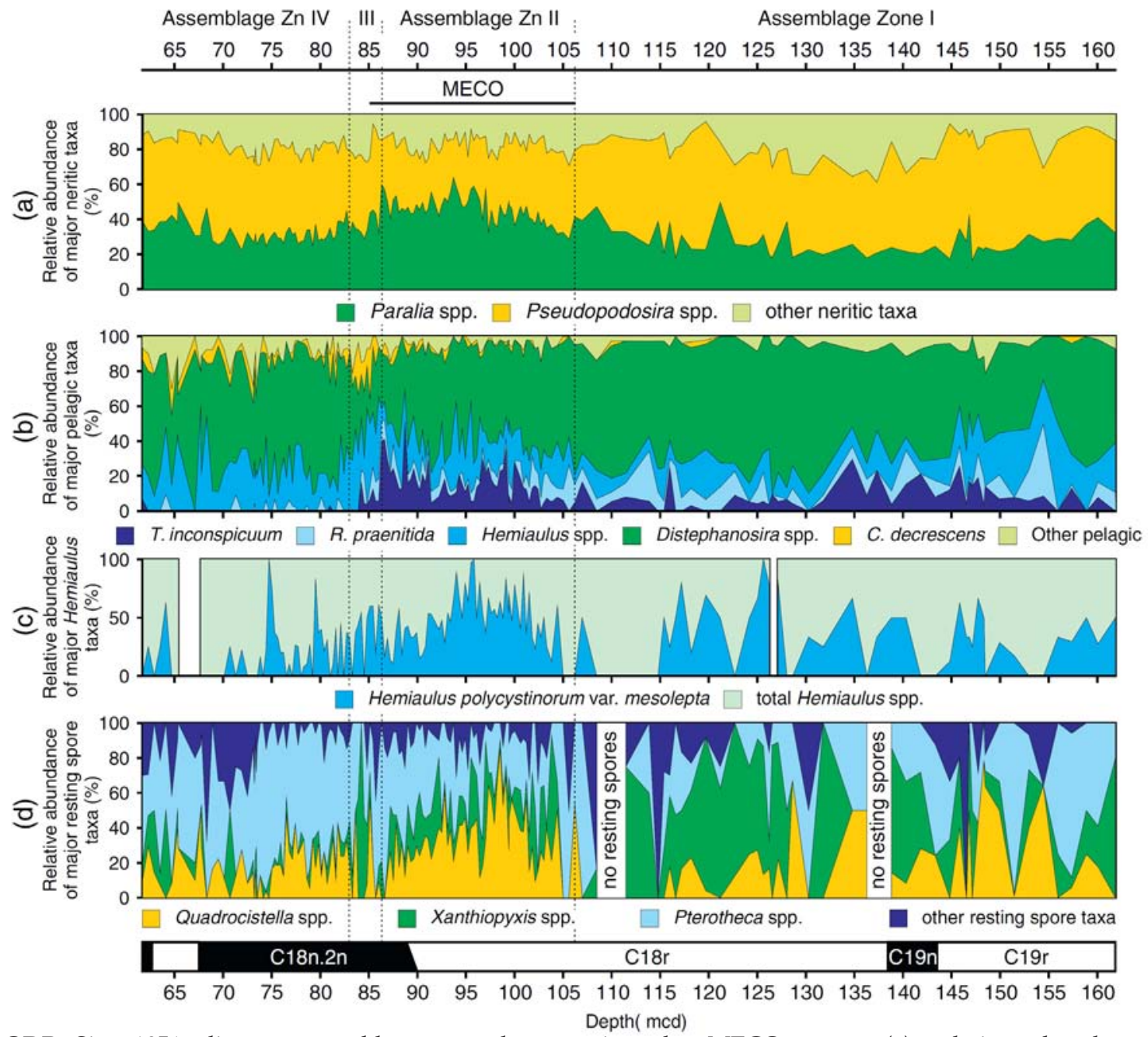

Figure 3. ODP Site 1051 diatom assemblage records spanning the MECO event: (a) relative abundance of major neritic taxa, (b) relative abundance of major pelagic taxa, (c) relative abundance of major species of Hemiaulus, (d) relative abundance of major resting spore taxa. Correlation based on Edgar et al. (2010). Dashed vertical lines represent boundaries of assemblage intervals discussed in the text. Abbreviations: mcd-meters composite depth.

defined as 'TSM Maximum 1' and 'TSM Maximum 2.' Within TSM Maximum 1, between 106.2 and $86.3 \mathrm{mcd}$, and TSM Maximum 2 between $\sim 83.0$ and $73.2 \mathrm{mcd}$, TSM abundance exceeds $\sim 9 \times 10^{6} \mathrm{~g}^{-1}$ (Fig. 2b). TSM Maximum 1 is associated with decreases in bulk and benthic $\delta^{18} \mathrm{O}$ values and bulk $\delta^{13} \mathrm{C}$ values (Fig. 2e-f), whereas TSM maximum 2 is associated with an increase in bulk $\delta^{13} \mathrm{C}$ and a short-lived decrease in bulk $\delta^{18} \mathrm{O}$ values at 79.5 mcd (Fig. 2b, e-f). TSM abundance decreases to minimum values between the two TSM maxima (Fig. 2b), coincident with the interval of the lowest bulk and benthic $\delta^{18} \mathrm{O}$ and $\delta^{13} \mathrm{C}$ values and a sharp $\sim 1 \%$ o positive shift in both bulk and benthic $\delta^{18} \mathrm{O}$ and $\delta^{13} \mathrm{C}$ values at 83.9 mcd (Fig. 2e-f).

\subsection{Diatoms}

A total of $\sim 150$ diatom taxa were identified in Site 1051 samples (Table 1 ). Neritic taxa comprise $\sim 78 \%$ of the diatom assemblage while pelagic forms and resting spores account for $\sim 13 \%$ and $\sim 5 \%$, respectively (Fig. 2c-d). The paleoecological associations of $\sim 4 \%$ of the diatom assemblage are uncertain due to provisional identifications (tabulated as 'Unidentified diatoms, vegetative valves' in Table S1) and thus are not discussed further (Fig. 2c). Trends in diatom absolute abundance parallel variations in TSM abundance, as expected given the dominance of diatoms in the siliceous microfossil assemblages (Fig. 2a-b, d).

The most abundant neritic diatom taxa present at Site 1051 are Paralia spp. ( Plate I, Figs. 9-10), Pseudopodosira spp. ( Plate I, Fig. 8), Rutilaria spp., and Rhaphoneis spp. ( Plate I, Fig. 1). Pseudopodosira spp. are more abundant than Paralia spp. between 148.5 and $102.1 \mathrm{mcd}$ and between 83.92 mcd and the top of the study interval at $61.7 \mathrm{mcd}$ ( Fig. 3a). However, there is a transient interval of increased relative abundance of Paralia between 102.1 

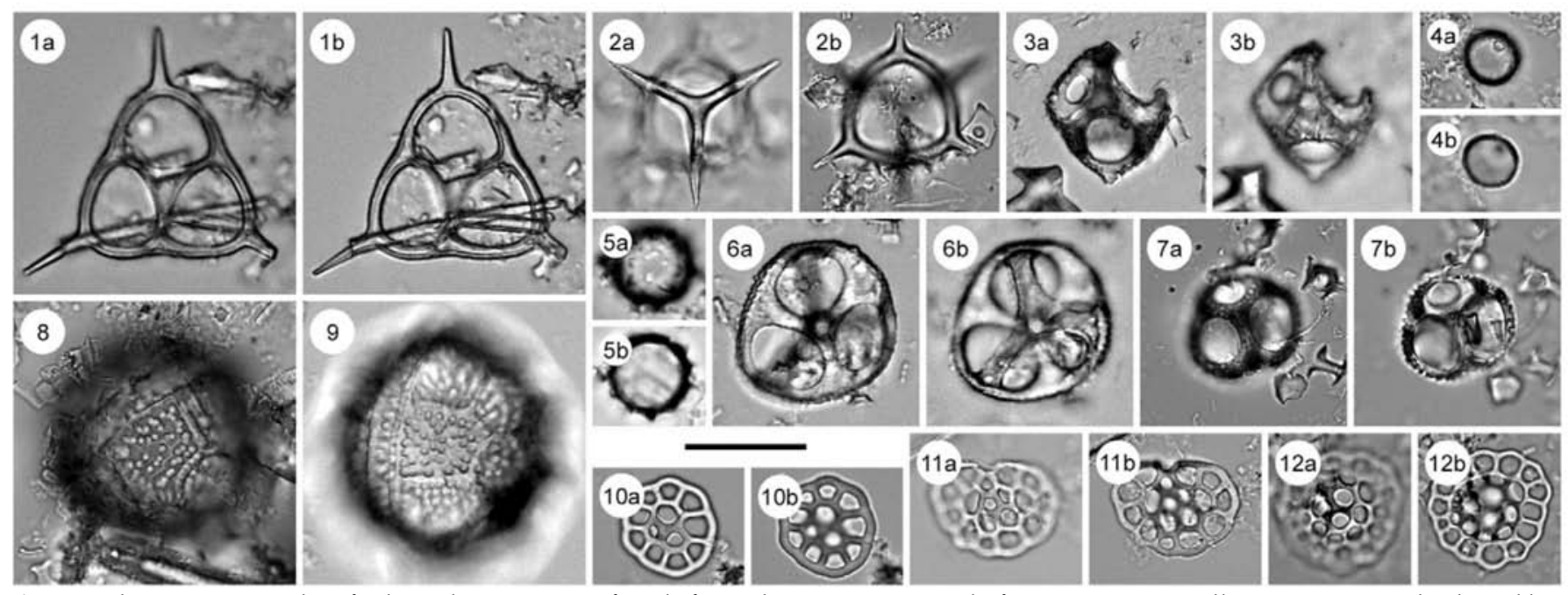

Plate II. Photomicrographs of other siliceous microfossils from the MECO interval of ODP Site 1051. All pairs represent high and low focus of the same specimen. Scale bar equals $20 \mu \mathrm{m}$, except for Figs. 5a-b (10 $\mu \mathrm{m})$. Fig. 1a-b. Corbisema regina, sample 171B-1051B15H-1, 4-5 cm. Fig. 2a-b. Corbisema spinosa, sample 171B-1051A-10H-1, 36-37 cm. Fig. 3a-b. Ebriopsis cornuta, sample 171B-1051A8H-2, 96-97 cm. Figs. 4-5. Chrysophycean cysts, sample 171B-1051A-9H-6, 126-127 cm. Fig. 6a-b. Ebriopsis crenulata, sample 171B-1051A-15H-6, 66-67 cm. Fig. 7a-b. Ebriopsis sp., sample 171B-1051A-10H-1, 66-67 cm. Figs. 8-9. Peridinites sphaericus?, samples 171B-1051A-9H-6, 126-127 cm (Fig. 8), 171B-1050A-2H-2, 33-34 cm (Fig. 9). Figs. 10-11. Macrora barbadensis, samples 171B-1051A10H-1, 6-7 cm (Fig. 10a-b), 171B-1051A-9H-2, 66-67 cm (Fig. 11a-b). Fig. 12a-b. Macrora stella, sample 171B-1051A-8H-2, 96-97 cm.

and 83.9 mcd ( Fig. 3a).

Among the pelagic diatoms (Fig. 3b), the most abundant taxa are Distephanosira spp. ( Plate I, Figs. 17-18), Hemiaulus spp. ( Plate I, Figs. 12-13), Rocella praenitida ( Plate. I, Fig. 20), Triceratium inconspicuum ( Plate I, Figs. 14-15) and Coscinodiscus decrescens ( Plate I, Fig. 16). A distinct increase in the relative abundance of T. inconspicuum occurs between 106.2 and $86.3 \mathrm{mcd}$ ( $\sim 15.5 \%$ on average, Fig. $3 b)$. Rocella praenitida is moderately abundant between 148.5 and 106.2 mcd ( 7.6\%), but its abundance gradually diminishes and shows an abrupt decline at $86.3 \mathrm{mcd}$ ( Fig. 3b). The abundance of Hemiaulus spp. (predominantly $H$. polycystinorum var. mesolepta, Fig. 3c) varies considerably throughout the study section, averaging $\sim 15.0 \%$ of the pelagic diatom assemblage between 148.5 and $106.2 \mathrm{mcd}, \sim 32.0 \%$ between 86.3 and $83.0 \mathrm{mcd}$, and $\sim 23.5 \%$ between 83.0 and $61.7 \mathrm{mcd}$ ( Fig. 3b). The relative abundance of Distephanosira is high throughout the study interval (> 55\%; Fig. $3 b)$, with only a transient decrease to $~ 14.3 \%$ between 86.3 and 83.0 mcd (Fig. 3b). This interval of low Distephanosira abundance is characterized by high relative abundance of C. decrescens (up to $\sim 29.7 \%$; Fig. 3b).

The diatom resting spore assemblages are represented by only a few taxa, with Pterotheca ( Plate I, Fig. 23), Quadrocistella (Plate I, Fig. 22), and Xanthiopyxis ( Plate I, Fig. 21) as the dominant genera. Although there are large variations in the relative abundance of resting spore taxa in the lower part of the section, the assemblage is dominated by Xanthiopyxis below $106.2 \mathrm{mcd}$, Quadrocistella between 106.2 and $86.3 \mathrm{mcd}$, and Pterotheca above 83.0 mcd ( Fig. 3d). Between 86.3 and $83.0 \mathrm{mcd}$, there are rapid variations in resting spore abundance, and, within a narrow interval at $84.2 \mathrm{mcd}$, Xanthiopyxis accounts for $100 \%$ of the resting spore assemblage ( Fig. 3d).

\subsection{Other siliceous microfossil groups}

Previous studies reported diverse and well-preserved middle Eocene radiolarian assemblages from Site 1051 (Shipboard Scientific Party, 1998a and Sanfilippo and Blome, 2001). Radiolarians comprise $\sim 23 \%$ of the siliceous microfossil assemblage on average throughout the study interval, with the exception of a large increase in their relative abundance between 87.2 and $83.0 \mathrm{mcd}$ (up to $\sim 60 \%$ ). This interval is coincident with a minimum in diatom abundance (Fig. 2a-b, Fig. S3a).

Throughout the study section, the abundances of silicoflagellates (Plate II, Figs. 1-2), ebridians (Plate II, Figs. 3, 6-7), chrysophyte cysts (Plate II, Figs. 4-5), siliceous dinoflagellates (Plate II, Figs. 8-9) and synurophyte scales (Plate II, Figs. 10-12) are generally low (Figs. S3b-S4). All of these groups, however, display similar trends to those observed in the diatom record, with elevated abundances between 106.2 and $86.3 \mathrm{mcd}$ and between 83.0 and 73.2 mcd (Figs. S3b-S4).

\subsection{Sediment density and accumulation rates}

There is an up-section decrease in sediment density beginning at $\sim 110 \mathrm{mcd}$ with a transient minimum at $\sim 85.8 \mathrm{mcd}$, where sediment density values reach as low 
(a) Distephanosira architecturalis

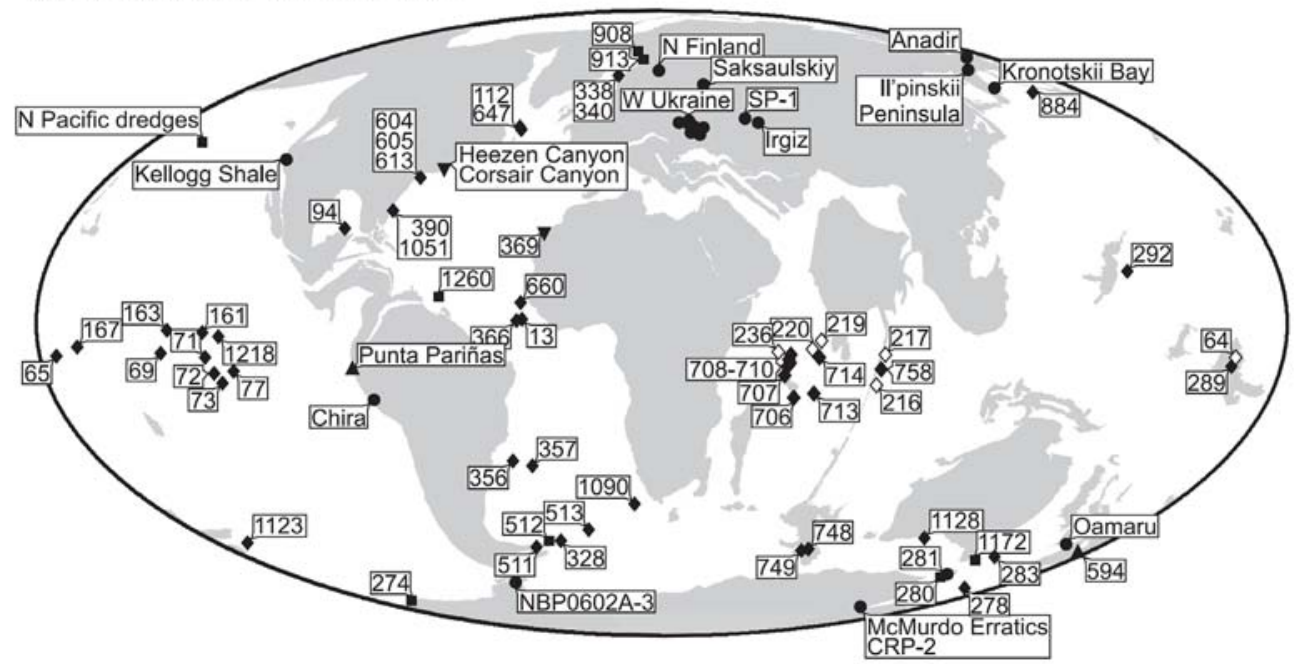

(b) Triceratium inconspicuum

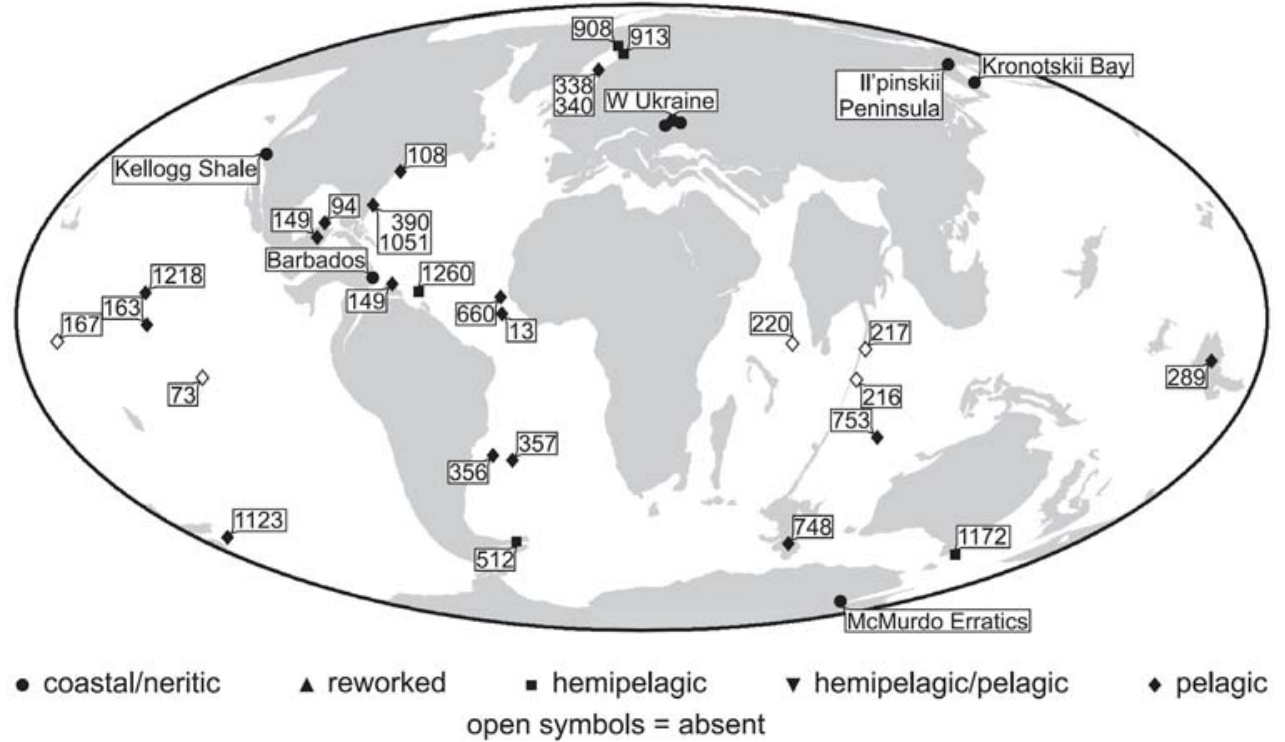

Figure 4.Global paleobiogeographic distribution of key pelagic diatom taxa recorded at ODP Site 1051, including (a) Distephanosira architecturalis in middle Eocene through late Oligocene successions, and (b) Triceratium inconspicuum in middle Eocene successions. See Tables S6-S9 in the online Supplementary materials for a list of references used in this compilation. Base maps: 40 Ma paleogeographic reconstruction generated using Ocean Drilling Stratigraphic Network Plate Tectonic Reconstruction service (www.odsn.de).

as $\sim 1.6 \mathrm{~g} / \mathrm{cm}^{3}$ (Fig. S5a). A decrease in sediment density is indicative of increasing biogenic opal content (Weber, 1998), which is consistent with our newly developed TSM record prior to the peak of TSM Maximum 1 at $93.4 \mathrm{mcd}$. Within the uppermost interval of the MECO, however, the sediment density record is likely biased by high radiolarian concentrations, perhaps due to the large size and high porosity of radiolarian tests (Fig. $\mathrm{S} 5 \mathrm{a}-\mathrm{b})$. These observations support the use of sediment density as an indicator of sediment composition, but also demonstrate that detailed microfossil assemblage records are necessary to aid the interpretation of GRAPE and DBD data.

Assessment of accumulation rates requires switching from the depth to age domain, which will be discussed from this point onwards. It should be noted that because of the low number of age control tie points in the available age model, the accumulation rate calculations presented here are approximate and likely average

Figure 5. Eocene through late Oligocene paleobiogeographic distribution of key pelagic diatom taxa recorded at ODP Site 1051: (a) Hemiaulus polycystinorum var. mesolepta, (b) Coscinodiscus decrescens, and (c) Rocella praenitida. See Tables S10-S15 in the online Supplementary materials for lists of references used in this compilation. Base maps: 40 Ma paleogeographic reconstruction generated using Ocean Drilling Stratigraphic Network Plate Tectonic Reconstruction service (www.odsn.de). 
(a) Hemiaulus polycystinorum var. mesolepta

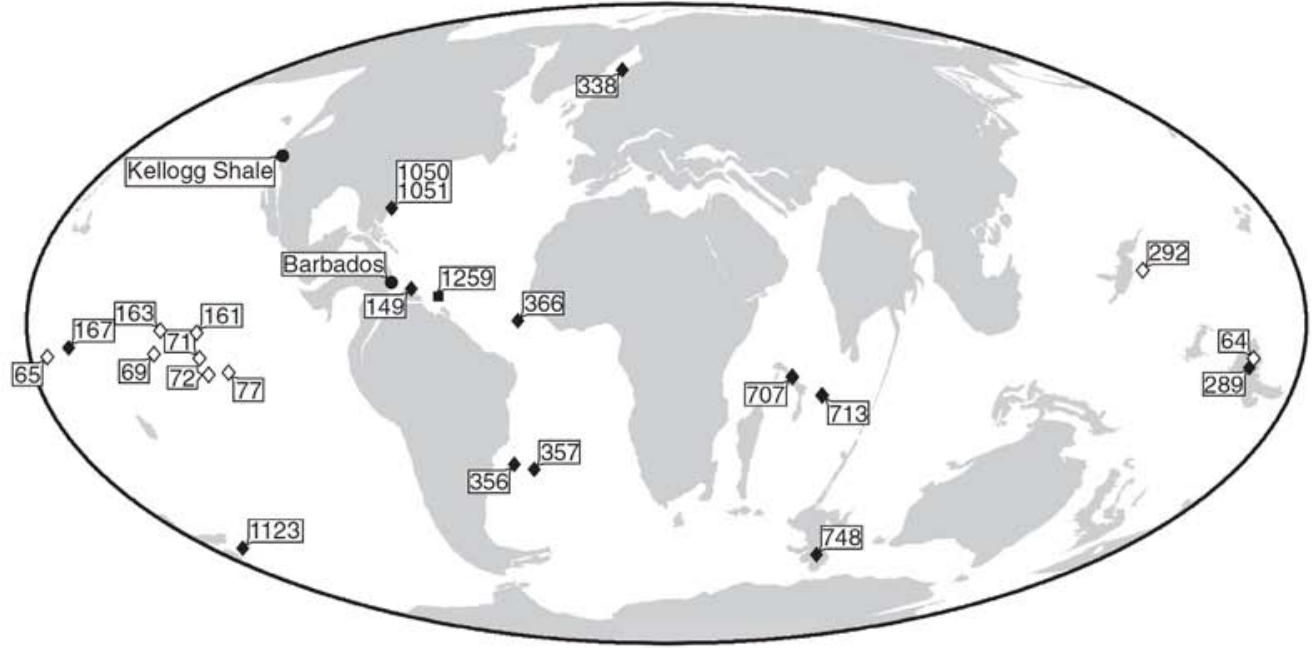

(b) Coscinodiscus decrescens

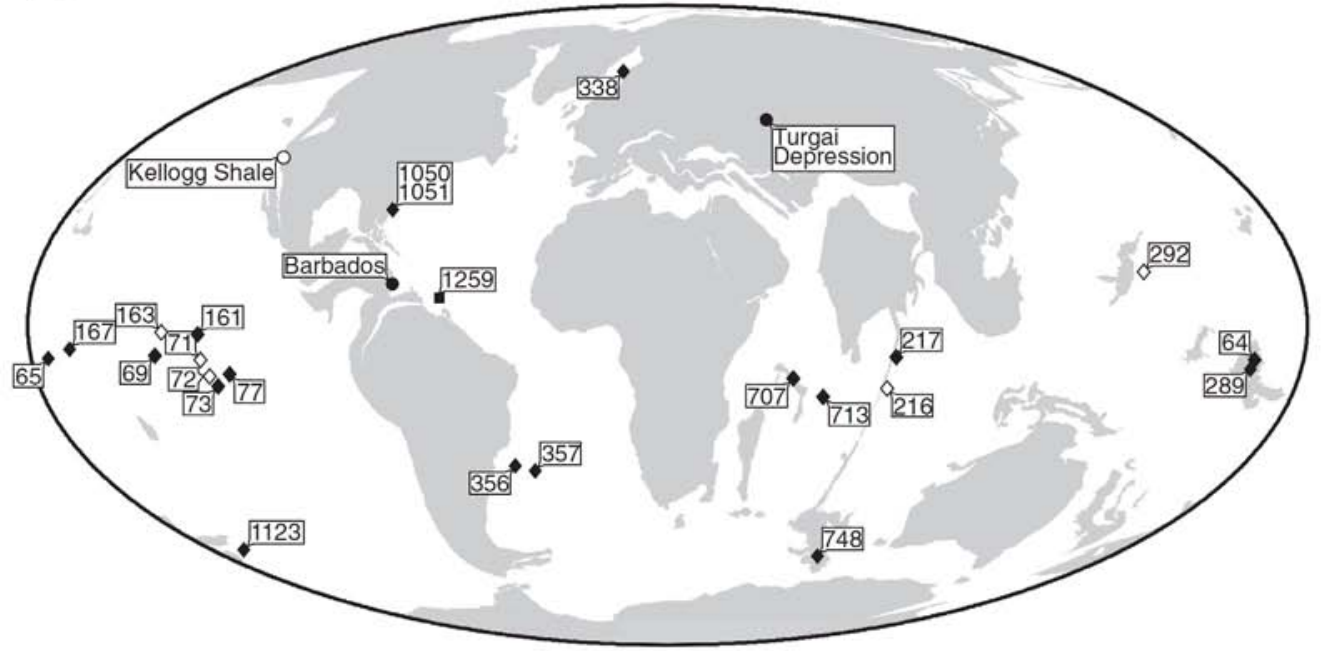

(c) Rocella praenitida

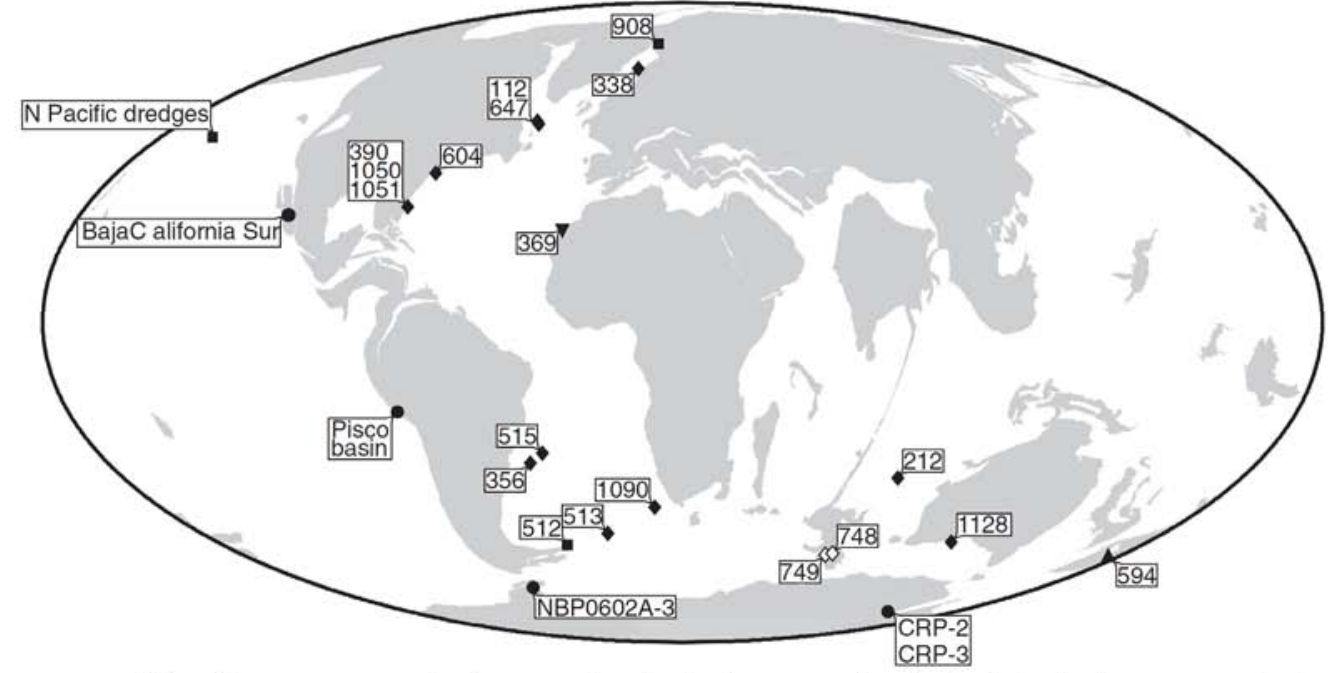

- coastal/neritic

A reworked

- hemipelagic

$\checkmark$ hemipelagic/pelagic

- pelagic open symbols $=$ absent 

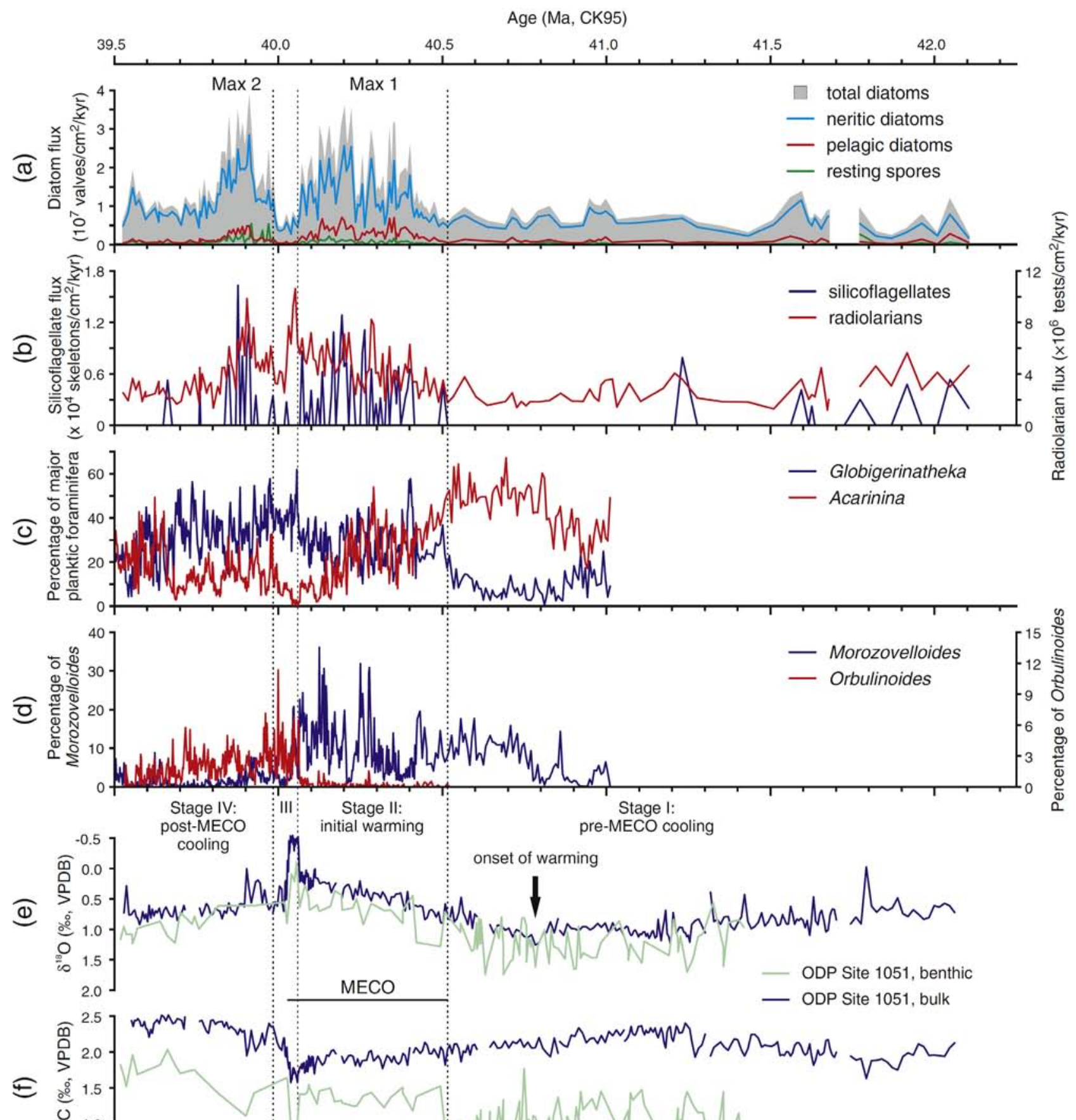
out short-term changes. Despite this caveat, elevated TSM accumulation rates are correlative with TSM maxima (Fig. S5d), suggesting that TSM abundance variations reflect pronounced changes in siliceous plankton production and sedimentation in the pelagic zone of the western North Atlantic Ocean (see further discussion in Section 5.1). Separate accumulation rate calculations were also made for total diatoms, neritic diatoms, pelagic diatoms, and resting spores (Fig. S5e), as well as for radiolarians and silicoflagellates (Fig. S5f-g). With the exception of radiolarians, accumulation rate changes for each of these groups parallel the overall trends in TSM fluxes.

\section{Interpretation}

\subsection{Diatom preservation}

The high alkalinity of pore-waters in carbonate-rich sediments tends to facilitate biogenic opal dissolution (Flower, 1993). For instance, diatom valves in middle Eocene sediments from Site 1051 commonly lack the most delicate parts of the valves, e.g., pore fields or areolae occlusions (Fig. S6c-e). However, Liostephania ( Plate I, Fig. 19), internal casts of diatoms regarded as indicators of enhanced dissolution (e.g., Hanna and Brigger, 1970) are sparse at Site 1051. Therefore, we interpret an overall moderate level of diatom dissolution across the entire study interval. Breakage is more common than dissolution at Site 1051, which most likely resulted from the offshore transport of neritic diatoms and a high degree of sediment bioturbation (Shipboard Scientific Party, 1998a).

Neritic diatoms are typically more heavily silicified than pelagic taxa, and their dominance throughout the study section is at least in part affected by preferential dissolution of pelagic taxa in the water column and on the seafloor. However, neritic diatoms consistently show poor-to-moderate preservation, while pelagic diatoms and resting spores identified tend to be moderately to well-preserved throughout the study interval. This suggests that there are no major temporal changes in siliceous microfossil preservation, and that diagenetic alteration is approximately uniform throughout the section. Thus, we interpret the intervals of elevated siliceous microfossil abundance and flux at Site 1051 to reflect primary changes in siliceous microfossil production and sedimentation in the western North Atlantic Ocean across the MECO, rather than secondary pro- cesses such as post-burial diagenesis.

\subsection{Diatom paleoecology}

Diatom-based paleoreconstructions commonly assume that all of the diatom assemblage is composed of in situ valves. Whereas such assumption is justified in studies on distal successions (e.g., Davies et al., 2009), diatom assemblages from more proximal localities, like ODP Sites 1051 or 1260 (Renaudie et al., 2010) (Fig. 1) need to be interpreted cautiously, as not all diatoms are well-suited for being indicators of open-ocean surface water conditions. Furthermore, our understanding of diatom paleoecology is often insufficient, which considerably reduces the paleoceanographic utility of early Paleogene diatoms. Based on the available paleobiogeographic, morphological, and ecological data, we provide a discussion below regarding the paleoecological preferences of the key diatom taxa observed in the Site 1051 study interval. These paleoecological inferences provide a basis for further paleoceanographic interpretation of the records.

Distephanosira architecturalis is one of the most common diatoms worldwide in middle-to-late Eocene sections. A compilation of published records (Tables S6-S7) indicates that this taxon had a cosmopolitan distribution in coastal, neritic and pelagic sites throughout its stratigraphic range ( Fig. 4a). Careful examination of morphological features (Fig. S6a-b) reveals a special adaptation for a planktic mode of life in the form of an empty chamber within the valve, presumably to increase buoyancy. Similarly, T. inconspicuum is common in both neritic and pelagic middle Eocene sediments (Tables S8-S9), which indicates a planktic mode of life ( Fig. 4b). Despite the scarcity of reports of $H$. polycystinorum var. mesolepta and C. decrescens in the literature (Tables S10S13), the cosmopolitan distribution of these species ( Fig. 5a-b), including numerous pelagic sites, strongly suggests a preference for an open-marine habitat. Rocella praenitida is absent from the Eocene-Oligocene intervals of tropical sites (Tables S14-S15), but it has a broad distribution in mid- and high-latitude Atlantic Ocean and at several Southern Ocean sites, which corroborates its pelagic affinity ( Fig. 5c). Based on these lines of reasoning, we regard the taxa assigned here as pelagic diatoms as representative of the paleoenvironmental conditions in the photic zone above Site 1051 in the pelagic western mid-latitude Atlantic Ocean. Thus, variations in abundance and assemblage structure of these pelagic dia-

Fig. 6. Synthesis of siliceous microfossil records from ODP Site 1051 across the MECO event compared with key planktic foraminiferal assemblage data and isotope records: (a) Diatom accumulation rates, (b) radiolarian and silicoflagellate accumulation rates, $(\mathrm{c}-\mathrm{d})$ relative abundance of major planktic foraminiferal groups, $(\mathrm{e}-\mathrm{f})$ bulk-carbonate and benthic $\delta^{18} \mathrm{O}$ and $\delta^{13} \mathrm{C}$ records, and $(\mathrm{g})$ surface-to-deep $\delta^{13} \mathrm{C}$ gradient $\left(\Delta \delta^{13} \mathrm{C}_{\text {bulk carbonate-benthic }}\right)$. Planktic foraminiferal assemblage and magnetostratigraphic data are from Edgar et al., 2010 and Edgar et al., 2013. Abbreviations: Max - TSM maximum; VPDB - Vienna Pee Dee Belemnite; CK95Cande and Kent (1995); GTS2012 - Gradstein et al. (2012). Dashed vertical lines represent boundaries of assemblage intervals. 
toms ( Fig. 3b) are used to infer changes in local siliceous microfossil production and surface-ocean hydrography.

The diatom assemblage at Site 1051 includes a number of heavily silicified, chain-forming taxa, e.g., Paralia, Pseudopodosira, and Rutilaria. A neritic paleoecology for these genera is inferred primarily by comparison to the environmental preferences of extant taxa (e.g., Ross, 1995 and McQuoid and Nordberg, 2003). Given the distribution of Paralia in the modern oceans, where it is restricted to littoral waters (e.g., Sawai et al., 2005 and Gebühr et al., 2009), we infer that it is unlikely that Paleogene species of Paralia had a pelagic affinity. Even early in its evolutionary history in the Cretaceous, Paralia was common in neritic environments (e.g., Canadian Margin, see Witkowski et al., 2011), and absent from pelagic settings (e.g., CESAR-6 drillcore; Davies et al., 2009). As a tychoplanktic diatom, Paralia can be transported over large distances, but its heavy silicification makes it primarily a neritic form ( Round et al., 1990).

The high abundance of neritic diatoms at Site 1051 (Figs. 2c-d) conflicts with the interpreted pelagic setting of this site during the middle Eocene, inferred mainly from sediment lithology (carbonate-rich oozes with low siliciclastic content), deep outer slope position on Blake Nose, and high abundance of planktic relative to benthic foraminifera (Shipboard Scientific Party, 1998a). Thus, the neritic diatoms deposited at Site 1051 are allochthonous and were transported from the adjacent shelf environments located to the west of Blake Plateau during the middle Eocene (see paleogeographic reconstruction in Galloway et al., 2011). The high abundance of tychoplanktic and neritic planktic taxa implies intense lateral transport by surface currents (e.g., Martin, 2003), and the presence of benthic diatoms such as Actinoptychus, Diplomenora, Mastogloia and Rhaphoneis (Table S3; see Plate I, Figs. 1-5) also indicates the role of bottom currents in transporting diatoms downslope from the shelf to Site 1051 (e.g., Kennett, 1982; see also Fenner and Hoff, 2011). Based on the absence of diatom zonal marker species that were extinct by the late middle Eocene (e.g., Triceratium kanayae, Pyrgupyxis caputavis; see Fenner, 1985), we think it unlikely that erosion and reworking of older strata provided the source of neritic diatoms recorded at Site 1051, and assume that the allochthonous diatoms are contemporaneous with the pelagic deposition at this site. Dinocyst assemblages at ODP Site 1053 (paleodepth: 500-700 m; Shipboard Scientific Party, 1998b) ( Fig. 1) also show a high percentage of transported neritic forms ( van Mourik et al., 2001). Site 1053, spanning magnetochrons C17r through C13r (mid- to late Eocene; Shipboard Scientific Party, $1998 \mathrm{~b}$ ) is more proximal, and is located at a shallower water depth than Site 1051. However, the high abun- dance of neritic dinocysts at Site 1053 corroborates persistent transport of shelf-dwelling microplankton from the North American continental margin in the Blake Nose area. Finally, the presence of allochthonous neritic diatoms and dinocysts in pelagic sediments at the Blake Nose indicates that other sedimentary components and microfossil groups may also be displaced from the adjacent shelf environments, although to date no direct evidence of transport from the shelf has been reported, e.g., in the foraminiferal or calcareous nannofossil assemblage records.

Some of the most abundant resting spore taxa at Site 1051, such as Quadrocistella and Xanthiopyxis (Fig. 3d), were likely produced by the planktic genus Chaetoceros ( Suto, 2004 and Suto, 2006). In the modern oceans, Chaetoceros is common in the neritic plankton (e.g., Hernández-Becerril, 1996 and Hasle and Syvertsen, 1997), but pelagic species are also known (e.g., Aizawa et al., 2005). Pterotheca is also present in high abundance at Site 1051 (Fig. 3d); this taxon is common in neritic settings from the Cretaceous onward, but its corresponding vegetative valves have not been determined ( Suto et al., 2009). Therefore, based on both possible neritic and pelagic paleoecological associations of the resting spore taxa recorded in this study, the resting spores were either part of neritic plankton communities that were transported to the open ocean, or they were produced and deposited in the pelagic zone in close proximity to Site 1051. Changes in the abundance of resting spore taxa may provide only indirect evidence for nutrient or stratification changes in surface waters either locally or in nearby shelf environments across the MECO, because their provenance is uncertain.

\subsection{Succession of diatom assemblages}

Based on the changes in relative abundance of neritic, pelagic and resting spore taxa, four diatom assemblage zones are distinguished at Site 1051 (Fig. 3 and Fig. 6, Table 4):

(1) Assemblage Zone I (41.68-40.52 Ma) is characterized by higher abundances of Pseudopodosira than Paralia ( Fig. 3a), generally higher abundances of R. praenitida than T. inconspicuum ( Fig. 3b), and the dominance of Xanthiopyxis among the resting spores ( Fig. 3d).

(2) In Assemblage Zone II (40.52-40.06 Ma), Paralia is more abundant than Pseudopodosira ( Fig. 3a), T. inconspicuum occurs in higher abundance than $R$. praenitida ( Fig. 3b), H. polycystinorum var. mesolepta is the dominant species of Hemiaulus ( Fig. 3c), and Quadrocistella is the dominant resting spore genus ( Fig. 3d).

(3) In Assemblage Zone III (40.06-39.98 Ma), Paralia and Pseudopodosira are present in approximately equal 
abundance ( Fig. 3a), Hemiaulus replaces Distephanosira as the most abundant pelagic form ( Fig. 3b), and there is a high percentage of $C$. decrescens present ( Fig. 3b). Among resting spores, the abundance of Pterotheca and Xanthiopyxis is highly variable ( Fig. 3d).

(4) Assemblage Zone IV (39.98-39. $50 \mathrm{Ma})$ is characterized by abundant Pseudopodosira ( Fig. 3a). Secondarily, among the pelagic diatoms, there is also a high abundance of Distephanosira in this zone ( Fig. 3b), and $H$. polycystinorum var. mesolepta is less abundant than other Hemiaulus spp. (Fig. 3c). The dominant resting spore is Pterotheca spp. (Fig. 3d).

The diatom assemblage zones defined here correspond to four distinct stages of sea-surface temperature (SST) evolution evidenced by benthic foraminiferal and bulk $\delta^{18} \mathrm{O}$ records (Fig. 6): Stage I includes the terminal phase of pre-MECO cooling (41.68-40.52 Ma); Stage II encompasses the prolonged onset of MECO warming (40.52-40.06 Ma); Stage III is a short interval spanning peak MECO warming and termination (40.06-39.98 $\mathrm{Ma})$; and Stage IV spans the post-MECO cooling interval (39.98-39.50 Ma).

\subsection{Temperature and nutrient level changes}

Surface-to-deep $\delta^{13} \mathrm{C}$ gradients $\left(\Delta \delta^{13} \mathrm{C}_{\text {bulk carbonate-benthic }}\right)$ are generally stable throughout Stage I and diatom flux is consistently low ( Fig. 6a, g), implying no significant changes in phytoplankton production during this interval. There is also minimal bulk and benthic $\delta^{18} \mathrm{O}$ variation between 41.68 and $40.80 \mathrm{Ma}$, further indicating no significant temperature change in surface or deep waters. The gradual onset of MECO warming is suggested by the progressive decrease in bulk $\delta^{18} \mathrm{O}$ values starting at $\sim 40.80 \mathrm{Ma}$ ( Fig. 6e). However, there is no apparent response to the interpreted onset of warming in the siliceous microfossil record ( Fig. 6a-b), which may suggest that SST warming was not associated with concomitant changes in nutrient levels and/or pelagic siliceous plankton production - reflecting either a low sensitivity or a small degree of environmental change at this time. In contrast, the thermophilic planktic foraminiferal genus Morozovelloides does increase in abundance synchronously with the onset of warming indicated by the $\delta^{18} \mathrm{O}$ records ( Fig. $6 \mathrm{~d}$ ), perhaps implying a greater temperature sensitivity of foraminifera than siliceous microfossils. Surface waters over Site 1051 were more oligotrophic prior to than during the MECO based on the low flux of pelagic diatoms and silicoflagellates in Stage I ( Fig. 6a-b). This interpretation is consistent with the high relative abundances of warm-water favoring, photosymbiotic taxa (e.g., Acarinina and Morozovelloides; Edgar et al., 2013) in planktic foraminiferal assemblages (Fig. 6c). The relatively high flux of neritic diatoms during Stage I also implies continuous transport of diatoms

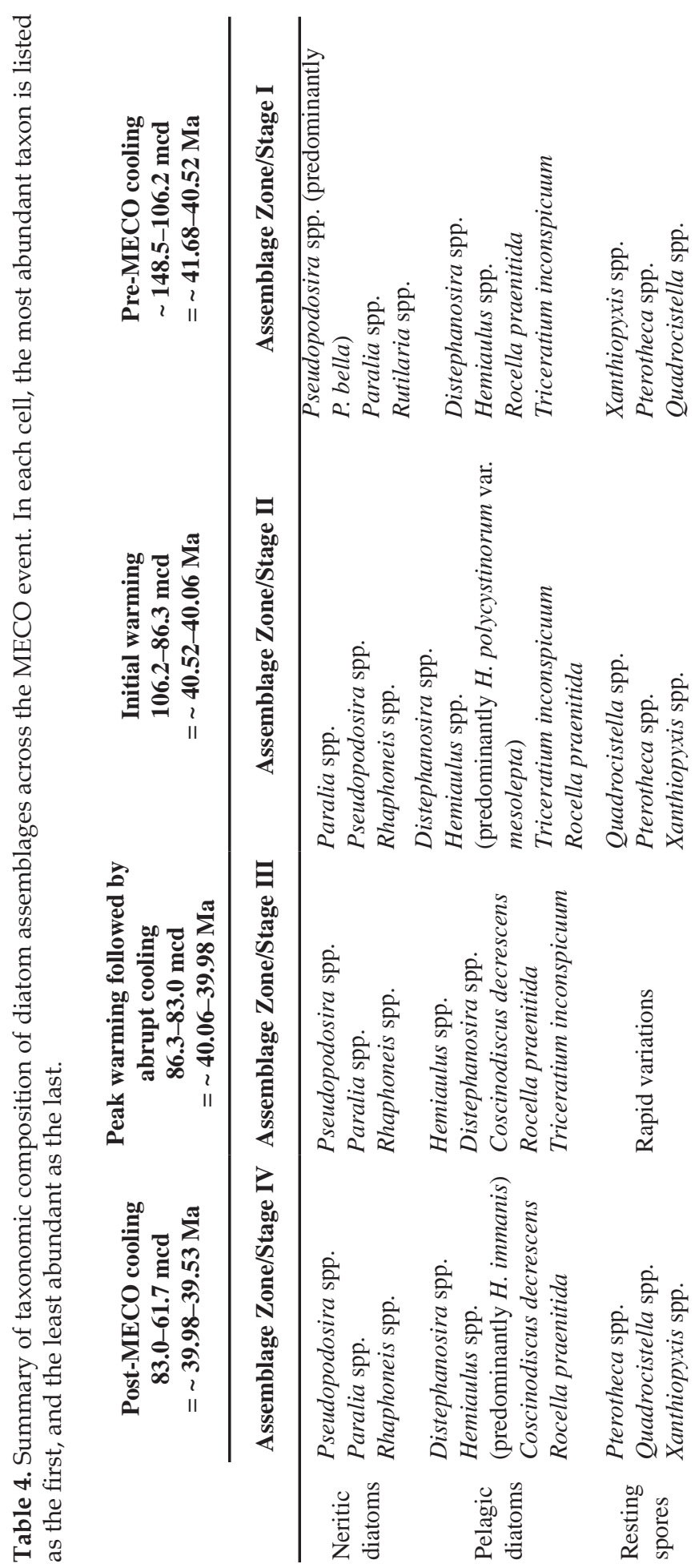


to Site 1051 by surface and bottom currents ( Figs. 6a, $7 a)$.

A pronounced increase in pelagic diatom flux at the beginning of Stage II (Figs. 6a, 7b) points to an increase in primary production in surface waters over Site 1051. The onset of this trend $(\sim 40.52 \mathrm{Ma})$ is coeval with the initiation of the MECO at other sites as identified by Bohaty et al. (2009), but postdates the gradual onset of warming at Site 1051. This increase in primary production is associated with continued surface and deepwater warming interpreted from decreasing bulk and benthic $\delta^{18} \mathrm{O}$ values (Fig. 6e). Eutrophication of surface waters is supported by relative decreases in the inferred warm, oligotrophic surface-dweller Acarinina ( Fig. 6c; Edgar et al., 2013). There is also an associated decrease in the $\Delta \delta^{13} C_{\text {bulk carbonate-benthic }}$ gradient in this interval, with values approaching 0 ( Fig. $6 \mathrm{~g}$ ), which could be interpreted to indicate a decline in export production or a decrease in nutrient utilization in the photic zone. However, compelling evidence for increased surface-water nutrient levels from multiple marine plankton groups argues against either of these alternative scenarios. Despite the evidence for continued increase in nutrient levels, both pelagic and total diatom fluxes peak at $\sim 40.2 \mathrm{Ma}$, and subsequently diminish ( Fig. 8b). This may indicate that at this time diatoms were outcompeted by other phytoplankton, who presumably utilized the available nutrients more efficiently.

Stage III is defined by a short-lived minimum in the flux of pelagic diatoms suggesting low diatom production during peak MECO warming and subsequent cooling (Figs. 6a, 7c). However, maximum radiolarian accumulation rates also occur in this interval at $40.05 \mathrm{Ma}$ (Fig. 8c). One plausible explanation for this peak in radiolarian abundance, offset $\sim 150 \mathrm{kyr}$ from the peak in total diatom flux, is that radiolarians grazed on the groups of non-siliceous phytoplankters that outcompeted diatoms during the interval of peak warming. Alternatively, the observed offset could result from increased radiolarian concentration due to winnowing. A rapid decline in radiolarian flux immediately follows this interval between 40.05 and 40.02 (Figs. 6b, 8c). Together, low diatom, silicoflagellate and radiolarian flux (Fig. 6b) suggest a decrease in pelagic plankton production associated with rapid cooling (Fig. 7c). Changes in planktic foraminiferal assemblages, most notably a rapid drop in the relative abundance of the thermophilic genus Morozovelloides ( Fig. 6d) support rapid sea-surface cooling interpreted from increasing $\delta^{18} \mathrm{O}$ values. The $\Delta \delta^{13} C_{\text {bulk carbonate-benthic }}$ values initially increase at 40.06 Ma within Stage III ( Fig. 6g), possibly indicating a transient rise in phytoplankton export production concomitant with the short-lived increase in radiolarian abundance.
At the beginning of Stage IV, pelagic diatom and silicoflagellate fluxes increase between 39.98 and $39.76 \mathrm{Ma}$, pointing to elevated nutrient levels in the surface ocean over Site 1051 (Figs. 6a-b, 7d). High flux of resting spores between 39.98 and 39.94 Ma (Fig. 6a) may suggest not only increased diatom production but also periodic stratification with nutrient depletion in the photic zone. $\Delta \delta^{13} C_{\text {bulk carbonate-benthic }}$ values increase at $\sim 39.9 \mathrm{Ma}$ ( Fig. $6 \mathrm{~g}$ ), possibly indicating more efficient nutrient utilization or elevated export production in the photic zone. The onset of this trend is associated with a relatively short-lived $(<100 \mathrm{kyr})$ negative excursion in bulk $\delta^{18} \mathrm{O}$ and $\delta^{13} \mathrm{C}$ values ( Fig. 6e-f), which can be interpreted as a minor warming event within the post-MECO cooling phase, as also suggested by a transient increase in the relative abundance of Morozovelloides ( Fig. 6d). After 39.76 Ma the diatom flux decreases, suggesting reduced nutrient availability in the surface waters at Site 1051 ( Fig. 6a) and a return to baseline conditions similar to, or warmer than, those immediately prior to the MECO event ( Fig. 7a, d). Similarly, planktic foraminiferal assemblages indicate a return to pre-MECO like conditions with relative increases and decreases in the percentage of Acarinina and Globigerinatheka, respectively ( Fig. 6c). However, the relative abundance of the warmwater indicator species Orbulinoides beckmanni also diminishes through Stage IV ( Fig. 6d) and may indicate SST cooling throughout this time interval ( Edgar et al., 2010).

To summarize, we interpret changes in siliceous microfossil assemblages at Site 1051 as a record of rapid fluctuations in pelagic siliceous phytoplankton production (Fig. 7). Two episodes of nutrient enrichment in the surface ocean are interpreted from siliceous microfossil assemblage changes between 41.7 and $39.5 \mathrm{Ma}$ : an $\sim 460 \mathrm{kyr}$ interval during the initial warming phase of the MECO (TSM Maximum 1 within Stage II), and an $\sim 220$ kyr period of nutrient enrichment within the initial post-MECO cooling phase (TSM Maximum 2 within Stage IV). The interpreted minimum in siliceous phytoplankton production between 40.06 and 39.98 Ma spans the interval of peak warming and abrupt cooling which terminated the MECO event (Fig. 8b).

\section{Discussion}

\subsection{Planktic vs. neritic diatom paleoenvironmental signals}

During initial shipboard work, the high abundance of diatoms in Eocene sediments at Site 1051 was interpreted to represent persistent high siliceous phytoplankton primary production (Shipboard Scientific Party, 1998a). In contrast, our high-resolution study shows that siliceous phytoplankton production was variable across the MECO interval. Due to a number of syn- and 
post-depositional processes, it is not possible to quantify past surface-water nutrient levels based on siliceous microfossil assemblage and accumulation rate variations alone. However, biosiliceous sediments deposited under upwelling regimes typically show diatom abundance in the range of $10^{9} \mathrm{~g}^{-1}$ (Davies et al., 2009). Maximum TSM concentration recorded here is in the range of $10^{6} \mathrm{~g}^{-1}$. Therefore, given the preservational issues outlined in Section 4.1, we conservatively interpret our diatom records to indicate that the trophic regime at Site 1051 ranged from moderately oligotrophic to mesotrophic - an interpretation consistent with planktic foraminiferal assemblages (Shipboard Scientific Party, 1998a, Edgar et al., 2010 and Edgar et al., 2013). Thus, continuous highly eutrophic conditions with sustained high siliceous phytoplankton production in surface waters are unlikely at Site 1051 during the late middle Eocene. Furthermore, it is also apparent that multiple paleoenvironmental signals are embedded in the middle Eocene diatom record at Site 1051. Our interpretation of the siliceous plankton production changes during the MECO at Site 1051 relies mainly on the pelagic diatoms and silicoflagellates. However, the dominant component of the siliceous microfossil assemblages are neritic diatoms (Fig. 6a). Thus, an important question arises: whether the variations in neritic diatom abundance and accumulation rates can be used to interpret changes in neritic diatom production on the adjacent continental shelf located to the west of Site 1051 (see paleogeographic reconstruction in Galloway et al., 2011).

While pelagic and neritic diatom assemblages show a similar pattern of variation between 41.7 and $39.5 \mathrm{Ma}$, the abundance and flux of neritic diatoms are considerably higher than those of pelagic diatoms and resting spores (Fig. 6a). This may suggest that nutrient levels were higher in the coastal zone of the western North Atlantic than in the open ocean at Site 1051. However, the high relative abundance of neritic diatoms, and, in particular, heavily silicified tychoplanktic diatoms (Pseudopodosira spp. and Paralia spp.) may be the result of preferential dissolution of the lightly silicified pelagic diatoms. Therefore, the changes in trophic status in the neritic zone of the western North Atlantic during the MECO may have followed the same pattern as in the pelagic zone, but their magnitude cannot be quantitatively constrained based on the displaced neritic diatom assemblages.

Another plausible interpretation of the high percentage of neritic diatoms at Site 1051 is that intervals of high neritic diatom flux may reflect changes in sea level or shelf accommodation space on the adjacent North American continental margin. Recent modeling efforts (Sømme et al., 2009) indicate that continental shelves during the Paleogene were broad and relatively shal- low, which enabled high sediment supply to the continental slope and basin floor. Increased sediment supply to the shelf, which should be expected during a period of a greenhouse warming because of the intensified hydrological cycle and elevated continental weathering rates (e.g., Sluijs et al., 2013), would have further reduced shelf accommodation space, possibly leading to increased neritic diatom flux offshore. This might explain the high abundance of neritic diatoms at Site 1051 within TSM Maximum 1 during Stage II. Furthermore, a relative rise in sea level during the peak warming phase would have increased the accommodation space, and thus caused a drop in neritic diatom accumulation during Stage III. Alternatively, high flux of neritic diatoms could have been caused by relative sea level rise or an increase in shelf accommodation space which created a broader neritic zone and thus more area for shelf diatom production. Such speculations require verification by other microfossil groups and independent sea-level proxies.

Overall, we infer that the high abundance of neritic diatoms at Site 1051 resulted from sustained transport of contemporaneous shelf-derived biogenic material by both surface and bottom currents throughout the middle Eocene study interval. In addition, the diatom assemblages have been subject to a minor-to-moderate degree of preferential dissolution which likely elevated the percentages of the heavily-silicified neritic diatoms. As such, the intervals of high neritic diatom abundance may reflect elevated diatom flux resulting from higher siliceous phytoplankton production in the neritic zone of the western North Atlantic Ocean during the onset of the MECO (TSM Maximum 1), and within the early phase of post-MECO cooling (TSM Maximum 2). Alternatively, the intervals of elevated neritic diatom accumulation rates could indicate changes in shelf accommodation space and/or sea level fluctuations. Given the evidence for downslope transport provided by diatoms from Site 1051 and dinocyst assemblages from Site 1053 (van Mourik et al., 2001), future studies on the Leg 171B sites should consider possible evidence for downslope transport in paleoenvironmental interpretations derived from micropaleontological and geochemical proxies.

\subsection{Integration of Site 1051 paleoproductivity signals with other MECO records}

Variations in surface-ocean primary production across the MECO have been interpreted at several sites around the globe based on a variety of proxies (Fig. 9a). At ODP Site 1218 in the equatorial Pacific, biogenic opal accumulation rates are highly variable throughout the Eocene (Lyle et al., 2005) and the MECO occurs within an interval of reduced biogenic opal accumulation (Lyle et al., 2005; Fig. 9a-b) -although opal accumula- 
(a) Stage I: Prior to $40.52 \mathrm{Ma}$

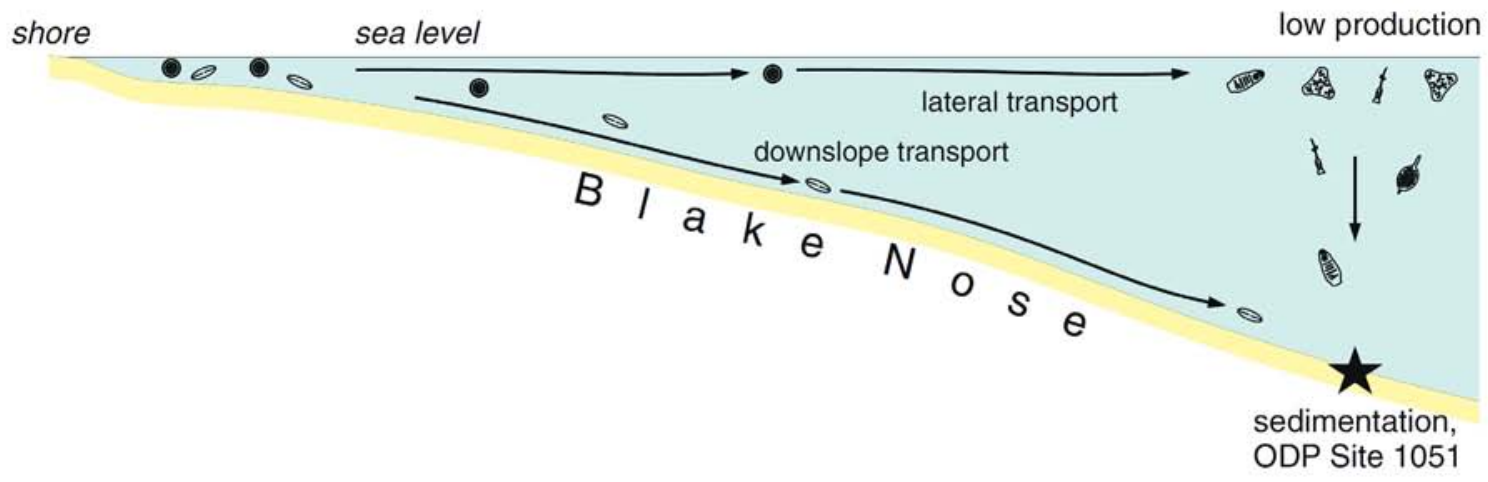

(b) Stage II: $40.52-40.06 \mathrm{Ma}$

increasing neritic diatom production? declining shelf accommodation space?

increased production

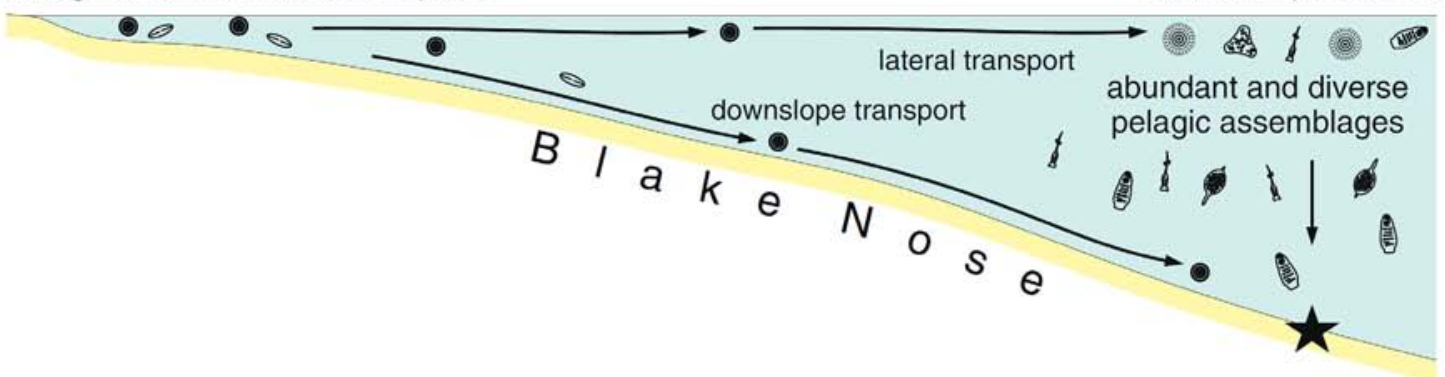

(c) Stage III: $40.06-39.98 \mathrm{Ma}$

minimum production

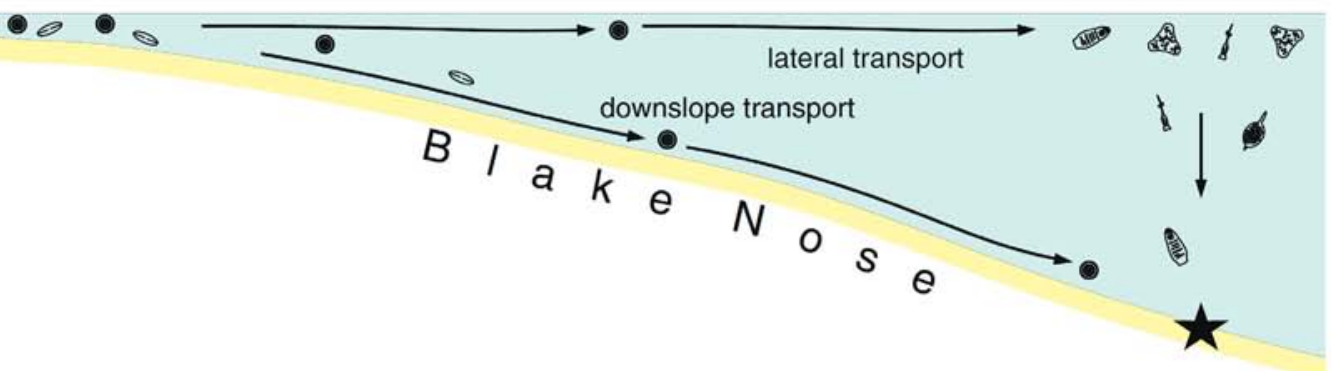

(d) Initial Stage IV: $39.98-39.76 \mathrm{Ma}$

increasing neritic diatom production? sea level drop?

increased production

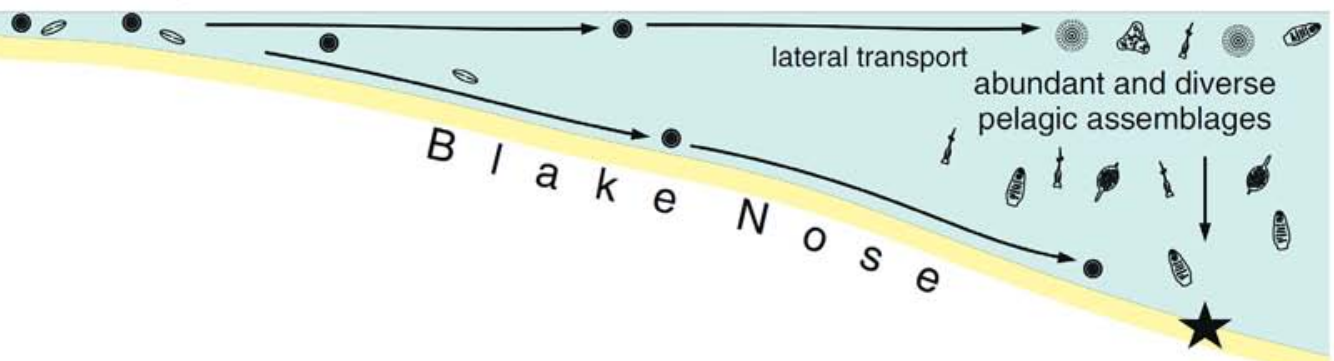


tion remained relatively high at this site for the entire late middle Eocene interval between $\sim 42$ and $38 \mathrm{Ma}$. Despite uncertainties in accumulation rate estimates at Site 1051 (e.g., due to the low-resolution age model and the LSRs), the record of pelagic diatom production at this site shows a different pattern than at Site 1218, with generally low flux inferred for the period prior to $40.5 \mathrm{Ma}$, and high accumulation rates interpreted during the MECO event (Fig. 9b). These differences are likely influenced by the contrasting paleoceanographic regimes of the sites in the middle Eocene: Site 1051 was located on a mid-latitude continental slope, and thus sensitive to changes in upwelling along the North American shelf margin and the local continental hydrological cycle which influenced nutrient supply to surface waters. In contrast, Site 1218 is an equatorial, open-ocean site at a paleodepth of $\sim 3000 \mathrm{~m}$ (Shipboard Scientific Party, 2002). In part because of the scarcity of deep-sea successions with well-preserved diatoms and reliable age control, the currently available datasets are insufficient to confidently speculate on global changes in biogenic silica accumulation across the MECO. These preliminary observations call for an increased effort to generate high-resolution biogenic opal records and quantitative siliceous microfossil accumulation records from other deep-sea successions, in order to provide an improved perspective on ocean fertility changes and silica cycling during the major climatic perturbations of the Paleogene.

A direct comparison of the timing of eutrophication between ODP Site 1051 and ODP Site $748\left(\sim 58^{\circ}\right.$ S, Kerguelen Plateau, Southern Ocean) may be complicated by an $\sim 50 \mathrm{kyr}$ misalignment of the peak of the MECO based on the current age models available for each site (Fig. S7c). The Eocene interval of Site 748 has an uninterpretable paleomagnetic signal (Roberts et al., 2003), and the age model developed by Bohaty et al. (2009) is based on correlation of stable isotope records between Site 748 and Southern Ocean ODP sites $702\left(50^{\circ} \mathrm{S}\right.$, Islas Orcadas Rise, South Atlantic) and 738 (62 $\mathrm{S}$, Kerguelen Plateau, Southern Ocean) that have interpretable, but not high quality, magnetostratigraphic age control. At Site 1051, the magnetostratigraphy is generally good, but a weak magnetic signal hinders confident placement of the base of Subchron C18n.2n ( $\pm 0.55 \mathrm{~m})$, which is crucial for dating of the peak of the MECO (Edgar et al., 2010). Future studies of the MECO in deep-sea successions with better age control, most notably sediments recovered during Integrated Ocean Drilling Program (IODP) Expeditions 320 (equatorial Pacific) and 342 (Newfoundland margin, North Atlantic), should help to resolve this discrepancy (Fig. S7c).

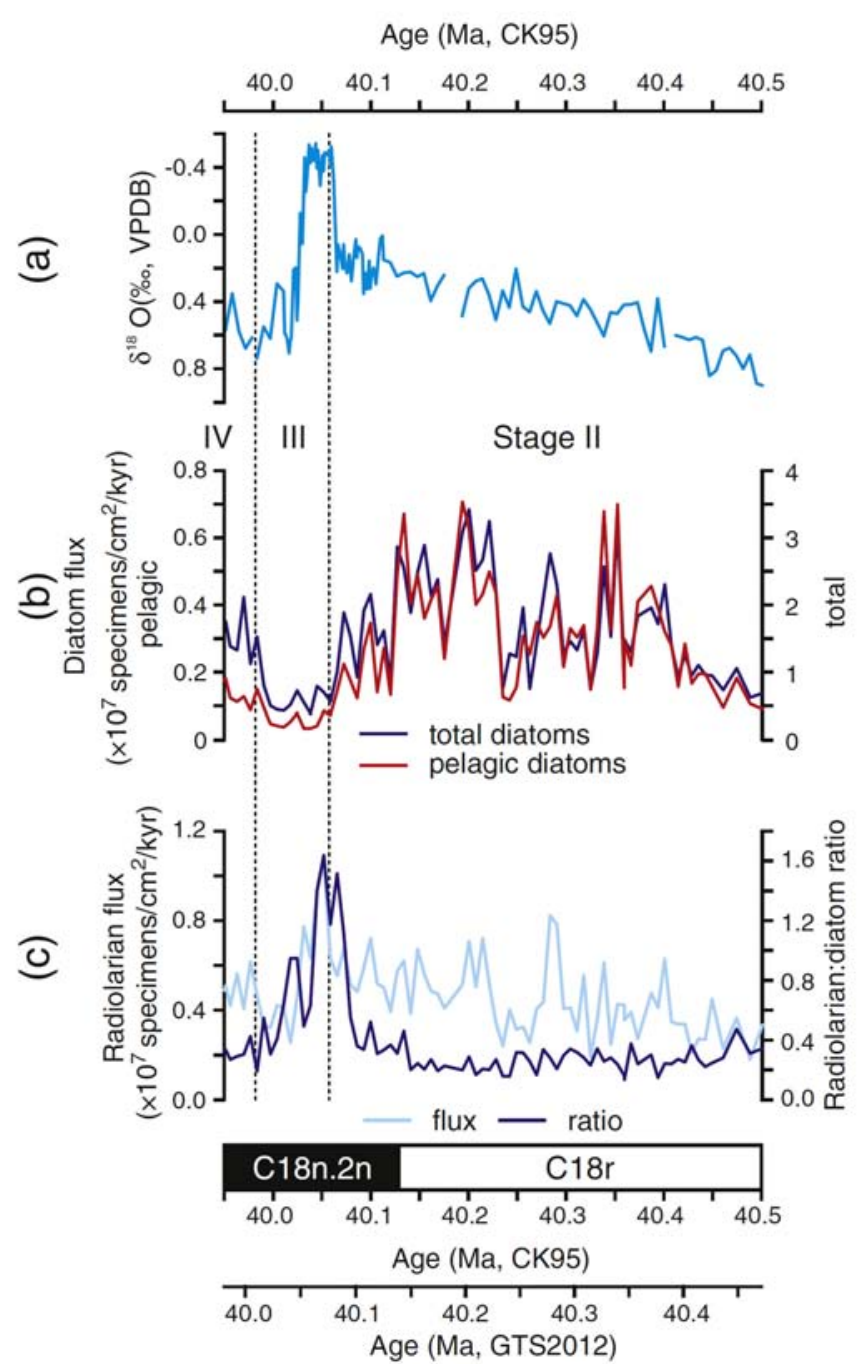

Figure 8. ODP Site $1051 \delta^{1 \triangleright} \mathrm{O}$ record across Stage II through initial Stage IV (a), plotted against differences in timing between peak fluxes of diatoms (b) and radiolarians, and radiolarian: diatom abundance ratio (c). Abbreviations: CK95-Cande and Kent (1995), VPDB-Vienna Pee Dee Belemnite; GTS2012-Gradstein et al. (2012).

Despite problems aligning the peak of the MECO, the overall trends in siliceous plankton accumulation through the MECO at Site 748 in the Southern Ocean (Witkowski et al., 2012; Fig. 9a) are similar to those observed at Site 1051. Oligotrophic surface waters are interpreted at both sites prior to the MECO, and an increase in pelagic siliceous phytoplankton production indicative of a shift to more eutrophic conditions is associated with increasing surface ocean SSTs during the initial warming phase of the MECO at both sites (Fig. 9c). Rapid cooling following the MECO coincides with a minimum in siliceous plankton production at Site 1051 and with a decline at Site 748 (Fig. 9c). However, biotic records from the MECO intervals of Sites 748 and 1051

Figure 7. Site 1051 reconstruction of sea surface temperature and nutrient availability changes across the MECO event (Stages I through IV) as interpreted from siliceous microfossil assemblage variations. Schematic drawings are not to scale. 

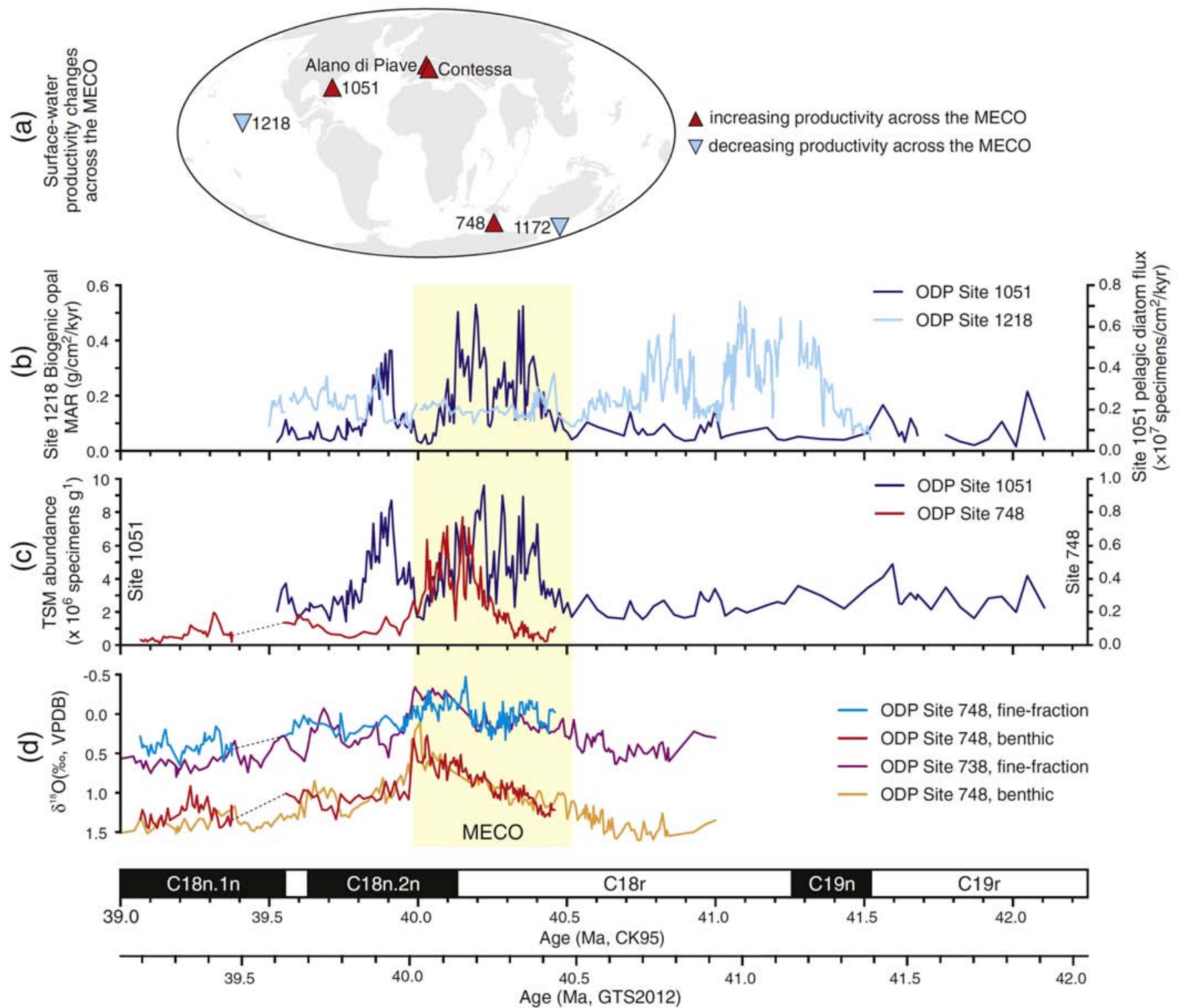

Figure 9. (a) Multi-proxy compilation of interpreted changes in surface ocean productivity across the MEC $\mathrm{O}$ in deep-sea and outcrop successions around the world, (b) comparison of biogenic opal mass accumulation rates atSite 1218 and pelagic diatom flux at Site 1051 , (c) comparison of trends in total siliceous microfossil abundance atSites 748 and 1051 (note difference in vertical scales), (d) fine-fraction and benthic $\delta^{18} \mathrm{O}$ records from the Southern Ocean sites 738 and 748. Based on data from Lyle et al. (2005), Bijl et al. (2010), Luciani et al. (2010), Spofforth et al. (2010), and Witkowski et al. (2012). Stable isotope data are from Bohaty et al. (2009). Magnetostratigraphic data from Edgar et al. (2010) Abbreviations: MAR - mass accumulation rate; TSM - total siliceous microfossils; VPDB - Vienna Pee Dee Belemnite; CK95-Cande and Kent (1995); GTS2012_Gradstein et al. (2012). Base map in panel (a): 40 Ma paleogeographic reconstruction generated using Ocean Drilling Stratigraphic Network Plate Tectonic Reconstruction service (www.odsn.de).

display considerable differences in the taxonomic composition of the assemblages (Fig. S7a-b). At Site 1051, diatoms are the dominant siliceous microfossil group, and silicoflagellates and ebridians are nearly absent (Fig. S7a-b), whereas at the Southern Ocean Site 748, silicoflagellates are the most abundant siliceous primary producer group, and ebridians and radiolarians make up the bulk of the siliceous microfossil assemblage (Fig. S7a-b). Furthermore, a post-MECO ( 39.9-39.7 Ma) increase in biosiliceous productivity (roughly equivalent to the peak flux during the MECO) is recorded at
Site 1051 in the Atlantic Ocean but not in the Southern Ocean (Fig. 9c).

In outcrop sections at Alano di Piave (Southern Alps, northern Italy; Fig. 9a), and Contessa Highway (northeastern Apennines, central Italy) (Jovane et al., 2007 and Luciani et al., 2010), geochemical proxies and foraminiferal and nannofossil assemblages also indicate significant eutrophication on the Tethyan margin in conjunction with the MECO event (Luciani et al., 2010, Spofforth et al., 2010, Toffanin et al., 2011 and Boscolo 
Galazzo et al., 2013). A more direct comparison between the deep-sea successions from sites 748 and 1051, and the Tethyan localities is hindered by the lack of biogenic opal/siliceous microfossil assemblage data from the Italian sections. Similarly, no siliceous microplankton assemblage data are currently available for the hemipelagic ODP Site $1172\left(44^{\circ} \mathrm{S}\right.$, East Tasman Plateau, southwest Pacific). However, changes in the peridinioidgonyaulacoid ratio in dinocyst assemblages indicate a decrease in nutrient levels across the MECO at this site (Bijl et al., 2010; Fig. 9a).

Based on the current range of available datasets, it is clear that the MECO had a geographically varied, but profound impact on plankton assemblages worldwide. A similar pattern of geographically disparate trends in surface ocean primary production is also identified at the Paleocene-Eocene Thermal Maximum (PETM) (e.g., Gibbs et al., 2006 and Stoll et al., 2007), reflecting the different relative influences of latitude, proximity to continents, upwelling zones, etc. Further study of the changes in surface ocean primary production during the major Paleogene global warming events may help to determine whether the geographically variable productivity patterns result from similar mechanisms and whether productivity patterns can provide insight on the operation of the carbon cycle (e.g., variations and mechanisms of marine carbon burial) during short-lived perturbations to the climate system.

\subsection{Global implications of the Site 1051 siliceous microfossil record across the MECO}

Diatoms are one of the key groups of primary producers in the modern oceans (Ragueneau et al., 2000). Owing to their rapid sinking as particulate debris in marine snow and within fecal pellets, diatoms also play an important role in organic carbon export to the deep ocean, which leads to carbon recycling or burial, and thus represents one mechanism regulating the quantity and cycling carbon in the ocean-atmosphere system (e.g., Yool and Tyrrell, 2003). The silicon residence time in the ocean is estimated at $\sim 10 \mathrm{kyr}$ (Tréguer and De La Rocha, 2013). Therefore, the siliceous microfossil record across the MECO interval of Site 1051 raises an important question: what conditions are necessary to sustain periods of elevated siliceous plankton production on the timescales of several $100 \mathrm{kyr}$ ?

Diatom growth is controlled by the availability of a range of nutrients, including nitrogen and phosphorus (Tappan, 1980), and silicic acid, which is supplied to the oceans mainly from riverine discharge, aeolian input, and hydrothermal and seafloor weathering sources (Yool and Tyrrell, 2003 and Tréguer and De La Rocha, 2013). Of these, the riverine input of continental weath- ering-derived silica provides the highest contribution to the total silica input flux to the ocean, and biogenic silica burial represents the primary output flux (Tréguer and De La Rocha, 2013). Thus, given the short residence time of silicon in the oceans, if diatom accumulation was elevated in some regions for $\sim 500 \mathrm{kyr}$, it implies that continental silicate weathering rates were enhanced during the MECO. This interpretation is consistent with an intensified hydrological cycle resulting from elevated atmospheric humidity, as previously invoked to explain the negative feedback mechanisms associated with climate warming during the PETM (e.g., Bowen et al., 2004).

Silicate weathering, in conjunction with carbonate deposition in the oceans, is the major sink for $\mathrm{CO}_{2}$ in the long-term carbon cycle (Walker et al., 1981 and Brady, 1991). The feedback between silicate weathering and atmospheric $\mathrm{CO}_{2}$ concentrations operates on timescales of $100 \mathrm{kyr}$ and longer (Zachos et al., 2008 and Sluijs et al., 2013), and thus is an important consideration for the relatively long duration of the MECO ( $500 \mathrm{kyr})$. Increased rates of silicate weathering likely modulated the rise in atmospheric $\mathrm{CO}_{2}$ levels during the MECO (Sluijs et al., 2013). Our records indicating increased rates of marine biogenic silica accumulation at Sites 748 and 1051 provide some support for the hypothesized increase in continental weathering during the MECO. However, the global picture of opal accumulation over the Cenozoic is not yet resolved, requiring data from many sites worldwide. Additionally, the causal mechanisms that drove the greenhouse warming during the MECO are still largely uncertain, and the relationship between elevated silicate weathering on land and longlived periods of carbonate dissolution in the deep sea poses a 'MECO conundrum' (see Sluijs et al., 2013). Further research on the distribution of biogenic silica sedimentation and marine primary production, as well as new data from shallow marine and terrestrial sedimentary systems, may shed more light on perturbations in continental weathering regimes during the MECO.

\section{Conclusions}

We document abundant siliceous microfossils within pelagic sediments at ODP Site 1051 across the late middle Eocene interval between 41.7 and 39.5 Ma. Diatoms and radiolarians are the most abundant siliceous microfossil groups in these sediments, while ebridians, silicoflagellates, chrysophyte cysts, siliceous dinoflagellates, and synurophyte scales constitute a minor component of the assemblages. Pronounced fluctuations in siliceous microfossil accumulation rates are recorded across the study interval. Two siliceous microfossil abundance maxima are identified: between 40.52 and 40.06 Ma during the initial warming stage of the MECO (TSM Maxi- 
mum 1), and between 39.98 and 39.76 Ma during the post-MECO cooling phase (TSM Maximum 2). These events are characterized by moderately high pelagic diatom and silicoflagellate accumulation rates, and are interpreted to represent enhanced pelagic siliceous plankton production. A prominent minimum in pelagic productivity is interpreted over a short interval between 40.06 and $39.98 \mathrm{Ma}$, which spans peak warming and the subsequent rapid cooling that terminated the MECO.

The diatom assemblage at Site 1051 is composed predominantly of allochthonous neritic diatoms, including mainly tychoplanktic, but also planktic and benthic forms. Therefore, sustained surface and bottom current transport of contemporaneous diatoms and sediment from the North American continental shelf is interpreted throughout the interval of study. We propose that the trends in neritic diatom accumulation rates may be interpreted as evidence for fluctuations in neritic primary production, or - alternatively - variations in sea level and/or shelf accommodation space on the North American margin located to the west of Site 1051. It is not clear, however, whether increases in accommodation space or a sea-level rise would result in an increase or decrease in transport of neritic diatom to offshore Site 1051.

Comparison of Site 1051 microfossil and stable isotope records with other sites across the MECO interval suggests a geographically varied response in surface ocean primary production to late middle Eocene greenhouse warming. The increase in siliceous plankton production over timescales of several $100 \mathrm{kyr}$ recorded at ODP sites 748 and 1051 indicates that elevated opal accumulation during the MECO may have been a widespread phenomenon and linked to enhanced input of silicic acid to the oceans. Thus, the siliceous microfossil record from Site 1051 lends support to the role of silicate weathering on land responding to and modulating an increase in atmospheric $\mathrm{CO}_{2}$ levels during the MECO.

Acknowledgements - This paper represents the second part of a PhD project completed by JW at the University of Warsaw under the advisorship of Ireneusz Walaszczyk. Funding for this research was provided by the Polish Ministry of Science and Higher Education with grant no. N N307 140838 to JW. Additional financial support for JW was provided by the Foundation for Polish Science ('Start' program). KE acknowledges research fellowship funding from the Natural Environment Research Council (NERC). The samples utilized in this study were provided by the Integrated Ocean Drilling Program. We thank Walter Hale and staff at the IODP Bremen Core Repository for efficient handling of several sample requests. We also wish to thank A. Sanfilippo, K. McCartney, B. Wawrzyniak-Wydrowska, S. Skompski, and W. Majewski for insightful discussions, construc- tive criticism, and numerous helpful suggestions. Chris Hollis and Peter Bijl are thanked for their constructive reviews and comments that greatly improved this paper.

\section{Appendix A. Supplementary data}

Supplementary data to this article can be found online at http:/ /dx.doi.org/10.1016/j.marmicro.2014.01.001.

\section{References}

Aizawa, C., Tanimoto,M., Jordan, R.W., 2005. Living diatomassemblages fromNorth Pacific and Bering Sea surface waters during summer 1999. Deep-Sea Res. II 52,2186$2205 . \quad$ http://dx.doi.org/10.1016/j.dsr2.2005.08.008.

Andersen, R.A., 1987. Synurophyceae Classis Nov., a new class of algae. Am. J. Bot. 74, 337-353.

Bains, S., Corfield, R.M., Norris, R.D., 1999. Mechanisms of climatewarming at the end of the Paleocene. Science 285, 724-727. http://dx.doi.org/10.1126/science.285.5428.724.

Bijl, P.K., Houben, A.J.P., Schouten, S., Bohaty, S.M., Sluijs, A., Reichart, G.J., Sinninghe Damsté, J.S., Brinkhuis, H., 2010. Transient middle Eocene atmospheric CO2 and temperature variations. Science 330, 819-821. http://dx.doi.org/10.1126/science.1193654.

Bohaty, S.M., Zachos, J.C., 2003. Significant Southern Ocean warming event in the late middle Eocene. Geology 31, 1017-1020.

Bohaty, S.M., Zachos, J.C., Florindo, F., Delaney, M.L., 2009. Coupled greenhouse warming and deep-sea acidification in the middle Eocene. Paleoceanography 24. http://dx.doi.org/10.1029/2008PA001676 (PA2207).

BoscoloGalazzo, F., Giusberti, L., Luciani, V., Thomas, E., 2013. Paleoenvironmental changes during the Middle Eocene Climatic Optimum (MECO) and its aftermath: the benthic foraminiferal record from the Alano section (NE Italy). Palaeogeogr. Palaeoclimatol. Palaeoecol. 378, 22-35. http://dx.doi.org/10.1016/j.palaeo.2013.03.018.

Bowen, G.J., Beerling, D.J., Koch, P.L., Zachos, J.C., Quattlebaum, T., 2004. A humid climate state during the Palaeocene/Eocene thermal maximum. Nature 432, 495-499.

Brady, P.V., 1991. The effect of silicateweathering on global temperature and atmospheric CO2. J. Geophys. Res. 96, 18101-18106. http://dx.doi.org/10.1029/91JB01898.

Cande, S.C., Kent, D.V., 1995. Revised calibration of the geomagnetic polarity timescale for the Late Cretaceous and Cenozoic. J. Geophys. Res. 100, 6093-6095.

Ciesielski, P.F., 1991. Biostratigraphy of diverse silicoflagellate assemblages from the early Paleocene to early Miocene of Holes 698A, 700B, 702B, and 703A: subantarctic South Atlantic. In: Ciesielski, P.F., Kristoffersen, Y. (Eds.), Proceedings of the Ocean Drilling Program, Scientific Results, 114, pp. 49-96. http:// dx.doi.org/10.2973/ odp.proc.sr.114.145.1991.

Cramer, B.S., Toggweiler, J.R.,Wright, J.D., Katz, M.E., Miller, K.G., 2009. Ocean overturning since the Late Cretaceous: inferences from a new benthic foraminiferal isotope compilation. Paleoceanography 24. http://dx.doi.org/10.1029/2008PA001683 (PA4216).

Davies, A., Kemp, A.E.S., Pike, J., 2009. Late Cretaceous seasonal ocean variability from the Arctic. Nature 460, 
254-259.

http://dx.doi.org/10.1038/nature08141.

Edgar, K.M.,Wilson, P.A., Sexton, P.F., Gibbs, S.J., Roberts, A.P., Norris, R.D., 2010. New biostratigraphic, magnetostratigraphic and isotopic insights into the Middle Eocene Climatic Optimum in low latitudes. Palaeogeogr. Palaeoclimatol. Palaeoecol. 297, 670682. http://dx.doi.org/10.1016/j.palaeo.2010.09.016.

Edgar, K.M., Bohaty, S.M., Gibbs, S.J., Sexton, P.F., Norris, R.D.,Wilson, P.A., 2013. Symbiont 'bleaching' in planktic foraminifera during theMiddle Eocene Climatic Optimum. Geology 41, 15-18. http://dx.doi.org/10.1130/G33388.1.

Ennyu, A., Arthur, M.A., Pagani, M., 2002. Fine-fraction carbonate stable isotopes as indicators of seasonal shallow mixedlayer paleohydrography. Mar. Micropaleontol. 46, 317-342.

Fenner, J., 1985. Late Cretaceous to Oligocene planktic diatoms. In: Bolli, H.M., Saunders, J.B., PerchNielsen, K. (Eds.), Plankton Stratigraphy. Cambridge University Press, Cambridge, pp. 713-762.

Fenner, J., Hoff, U., 2011. Marine diatoms in the Paleocene of the SW-Pacific. In: Egger, H. (Ed.), Climate and Biota of the Early Paleogene, Conference Program and Abstracts. Berichte der Geologischen Bundesanstalt, 85, p. 73.

Flower, R.J., 1993. Diatom preservation: experiments and observations on dissolution and breakage in modern and fossil material. Hydrobiologia 269 (270), 473-484.

Galloway, W.E., Whiteaker, T.L., Ganey-Curry, P., 2011. History of Cenozoic North American drainage basin evolution, sediment yield, and accumulation in the Gulf of Mexico basin. Geosphere 7, 938-973. http://dx.doi.org/10.1130/GES00647.1.

Gebühr, C., Wiltshire, K.H., Aberle, N., van Beusekom, J.E.E., Gerdts, G., 2009. Influence of nutrients, temperature, light and salinity on the occurrence of Paralia sulcata at Helgoland Roads, North Sea. Aquat. Biol. 7, 185-197. http://dx.doi.org/10.3354/ab00191.

Gibbs, S.J., Bralower, T.J., Bown, P.R., Zachos, J.C., Bybell, L.M., 2006. Shelf and open-ocean calcareous phytoplankton assemblages across the Paleocene-Eocene Thermal Maximum: implications for global productivity gradients. Geology 34, 233-236. http://dx.doi.org/10.1130/G22381.1.

Gradstein, F.M., Ogg, J.G., Schmitz, M.D., Ogg, G.M. (Eds.), 2012. The Geologic Time Scale. Elsevier, Oxford.

Hanna, GD., Brigger, A.L., 1970. Observations on Liostephania. In: Gerloff, J., Cholnoky, B.J., Gerloff, J., Cholnoky, B.J. (Eds.), Diatomaceae II. Friedrich Hustedt Gedenkband. 31. Nova Hedwigia, Beiheft, pp. 89-100.

Harding, I.C., Lewis, J., 1994. Siliceous dinoflagellate thecal fossils from the Eocene of Barbados. Palaeontology 37, 825-840.

Hasle, G.R., Syvertsen, E.E., 1997.Marine diatoms. In: Tomas, C.R. (Ed.), Identifying Marine Phytoplankton. Academic Press, San Diego, pp. 5-386.

Hernández-Becerril, D.U., 1996. A morphological study of Chaetoceros species (Bacillariophyta) from the plankton of the Pacific Ocean of Mexico. Bulletin of the Natural History Museum. Botany Series, 26, pp. 1-73.

Hollis, C.J., Rodgers, K.A., Parker, R.J., 1995. Siliceous plankton bloom in the earliest Tertiary of Marlborough, New Zealand. Geology 23, 835-838.

Jordan, R.W., Stickley, C.E., 2010. Diatoms as indicators of paleoceanographic events. In: Smol, J.P., Stoermer, E.F. (Eds.), The Diatoms: Applications for the Environmental and Earth Sciences. 2nd edition. Cam- bridge University Press, Cambridge, pp. 424-453.

Jovane, L., Florindo, F., Coccioni, R., Dinarès-Turell, J., Marsili, A., Monechi, S., Roberts, A.P., Sprovieri, M., 2007. Themiddle Eocene climatic optimum event in the Contessa Highway section, Umbrian Apennines, Italy. GSA Bull. 119, 413-427. http://dx.doi.org/10.1130/B25917.1. Kennett, J.P., 1982. Marine Geology. Prentice-Hall, New Jersey. Luciani, V., Giusberti, L., Agnini, C., Fornaciari, E., Rio, D., Spofforth, D.J.A., Pälike, H., 2010. Ecological and evolutionary response of Tethyan planktonic foraminifera to the middle Eocene climatic optimum (MECO) from the Alano section (NE Italy). Palaeogeogr. Palaeoclimatol. Palaeoecol. 292, 82-95. http:/ / dx.doi.org/10.1016/j.palaeo.2010.03.029.

Lyle, M., Olivarez Lyle, A., Backman, J., Tripati, A., 2005. Biogenic sedimentation in the Eocene equatorial Pacific-the stuttering greenhouse and Eocene carbonate compensation depth. In: Wilson, P.A., Lyle, M., Firth, J.V. (Eds.), Proceedings of the Ocean Drilling Program, Scientific Results, 199, pp. 1-35. http:// dx.doi.org/10.2973/ odp.proc.sr.199.219.2005 (Online).

Martin, A.P., 2003. Phytoplankton patchiness: the role of lateral stirring and mixing. Prog. Oceanogr. 57, 125-174. http://dx.doi.org/10.1016/S0079-6611(03)00085-5.

Matsuoka, A., 2007. Living radiolarian feeding mechanisms: new light on past marine ecosystems. Swiss J. Geosci. 100, 273-279. http://dx.doi.org/10.1007/s00015-007- 1228-y.

McQuoid, M.R., Nordberg, K., 2003. The diatom Paralia sulcata as an environmental indicator species in coastal sediments. Estuar. Coast. Shelf Sci. 56, 339-354. http: / / dx.doi.org/10.1016/S0272-7714(02)00187-7.

Mita, I., 2001. Data report: early to late Eocene calcareous nannofossil assemblages of Sites 1051 and 1052, Blake Nose, Northwestern Atlantic Ocean. In: Kroon, D., Norris, R.D., Klaus, A. (Eds.), Proceedings of the Ocean Drilling Program, Scientific Results, 171B, pp. 1-28. http:// dx.doi.org/10.2973/odp.proc.sr.171B.122.2001 (Online).

Ogg, J.G., Bardot, L., 2001. Aptian through Eocene magnetostratigraphic correlation of the Blake Nose Transect (Leg 171B), Florida Continental Margin. In: Kroon, D., Norris, R.D., Klaus, A. (Eds.), Proceedings of the Ocean Drilling Program, Scientific Results, 171B, pp. 1-58. http:// dx.doi.org/10.2973/odp.proc.sr.171B.104.2001 (Online).

Preisig, H.R., 1994. Siliceous structures and silicification in flagellated protists. Protoplasma 181, 29-42. http://dx.doi.org/10.1007/BF01666387.

Ragueneau, O., Tréguer, P., Leynaert, A., Anderson, R.F., Brzezinski, M.A., DeMaster, D.J., Dugdale, R.C., Dymond, J., Fischer, G., François, R., Heinze, C., Maier-Reimer, E., Martin-Jézéquel, V., Nelson, D.M., Quéguiner, B., 2000. A review of the $\mathrm{Si}$ cycle in the modern ocean: recent progress and missing gaps in the application of biogenic opal as a paleoproductivity proxy. Glob. Planet. Chang. 26, 317365. http://dx.doi.org/10.1016/S0921-8181(00)00052-7.

Renaudie, J., Danelian, T., Saint Martin, S., Le Callonec, L., Tribovillard, N., 2010. Siliceous phytoplankton response to a middle Eocene warming event recorded in the tropical Atlantic (Demerara Rise, ODP Site 1260A). Palaeogeogr. Palaeoclimatol. Palaeoecol. 286, 121134. $\quad$ http://dx.doi.org/10.1016/j.palaeo.2009.12.004. Roberts, A.P., Bicknell, S.J., Byatt, J., Bohaty, S.M., Florindo, F., Harwood, D.M., 2003. Magnetostratigraphic calibration of Southern Ocean diatom datums from the Eocene- Oligo- 
cene of Kerguelen Plateau (Ocean Drilling Program sites 744 and 748). Palaeogeogr. Palaeoclimatol. Palaeoecol. 198, 145168. http://dx.doi.org/10.1016/ S0031-0182(03)00397-3.

Ross, R., 1995. A revision of Rutilaria Greville (Bacillariophyta). Bulletin of the British Museum (Natural History). Botany Series, 25, pp. 1-93.

Round, F.E., Crawford, R.M., Mann, D.G., 1990. The Diatoms. Biology \& Morphology of the Genera. Cambridge University Press, Cambridge. Sanfilippo, A., Blome, C.D., 2001. Biostratigraphic implications of mid-latitude Palaeocene-Eocene radiolarian faunas from Hole 1051A, ODP Leg 171, Blake Nose, western North Atlantic. In: Kroon, D., Norris, R.D., Klaus, A. (Eds.), Western North Atlantic Palaeogene and Cretaceous Palaeoceanography. Geological Society of London Special Publications, 183, pp. 185-224.

Sawai, Y., Nagumo, T., Toyoda, K., 2005. Three extant species of Paralia (Bacillariophyceae) along the coast of Japan. Phycologia 44, 517-529.

Schrader, H.-J., Gersonde, R., 1978. Diatoms and silicoflagellates. In: Zachariasse, W.J. (Ed.), Micropaleontological Counting Methods and Techniques: An Exercise of an Eight Metres Section of the Lower Pliocene of Cap Rossello, Sicily. Utrecht Micropalaeontological Bulletin, 17, pp. 129-176.

Shipboard Scientific Party, 1998a. Site 1051. In: Norris, R.D., Kroon, D., Klaus, A., et al. (Eds.), Proceedings of the Ocean Drilling Program. Initial Reports, 171B, pp. 171-239. http:/ / dx.doi.org/10.2973/odp.proc.ir.171B.105.1998.

Shipboard Scientific Party, 1998b. Site 1053. In: Norris, R.D., Kroon, D., Klaus, A., et al. (Eds.), Proceedings of the Ocean Drilling Program. Initial Reports, 171B, pp. 321-348. http:/ / dx.doi.org/10.2973/odp.proc.ir.171B.107.1998.

Shipboard Scientific Party, 2002. Site 1218. In: Lyle, M., Wilson, P.A., Janecek, T.R., et al. (Eds.), Proceedings of the Ocean Drilling Program, Initial Reports, 199, pp. 1-126. http:// dx.doi.org/10.2973/odp.proc.ir.199.111.2002 (Online).

Sluijs, A., Zeebe, R.E., Bijl, P.K., Bohaty, S.M., 2013. A middle Eocene carbon cycle conundrum. Nature Geoscience Advance Online Publication, pp. 1-6. http://dx.doi.org/ 10.1038/NGEO1807.

Sømme, T.O., Helland-Hansen, W., Granjeon, D., 2009. Impact of eustatic amplitude variations on shelf morphology, sediment dispersal, and sequence stratigraphic interpretation: icehouse versus greenhouse systems. Geology 37, 587-590. http://dx.doi.org/10.1130/G25511A.1.

Spofforth, D.J.A., Agnini, C., Pälike, H., Rio, D., Fornaciari, E., Giusberti, L., Luciani, V., Lanci, L., Muttoni, G., 2010. Organic carbon burial following the middle Eocene climatic optimum in the central western Tethys. Paleoceanography 25. http://dx.doi.org/10.1029/2009PA001738 (PA3210).

Stickley, C.E., Koç, N., Brumsack, H.-J., Jordan, R.W., Suto, I., 2008. A siliceousmicrofossil view of middle Eocene Arctic paleoenvironments: a window of biosilica production and preservation. Paleoceanography 23, PA1S14. http://dx.doi.org/10.1029/2007PA001485.

Stoll, H.M., Shimizu, N., Archer, D., Ziveri, P., 2007. Coccolithophore productivity response to greenhouse event of the Paleocene-Eocene Thermal Maximum. Earth Planet. Sci. Lett. 258, 192-206. http://dx.doi.org/10.1016/j.eps1.2007.03.037.

Suto, I., 2004. Fossil marine diatom resting spore morpho-genus Xanthiopyxis Ehrenberg in the North
Pacific and Norwegian Sea. Paleontol. Res. 8, 283-310.

Suto, I., 2006. Taxonomy of the fossil marine diatom resting spore morpho-genera Xanthioisthmus Suto gen. nov. and Quadrocistella Suto gen. nov. in the North Pacific and Norwegian Sea. J. Micropalaeontol. 25, 3-22.

Suto, I., Jordan, R.W., Watanabe,M., 2009. Taxonomy of middle Eocene diatom resting spores and their allied taxa from the central Arctic Basin. Micropaleontology 55, 259-312.

Tappan, H., 1980. Paleobiology of Plant Protists. W.H. Freeman and Company, San Francisco.

Toffanin, F., Agnini, C., Fornaciari, E., Rio, D., Giusberti, L., Luciani, V., Spofforth,D.J.A., Pälike, H., 2011. Changes in calcareous nannofossil assemblages during the Middle Eocene Climatic Optimum: clues from the central-western Tethys (Alano section, NE Italy).

Mar. Micropaleontol. 81, 22-31. http://dx.doi. org / $10.1016 / \mathrm{j} . \mathrm{m}$ a r m i c r o. 2011.07 .002 .

Tréguer, P.J., De La Rocha, C.L., 2013. The World Ocean silica cycle. Annu. Rev. Mar. Sci. 5, 477-501. http:// dx.doi.org/10.1146/annurev-marine-121211-172346.

van Mourik, C.A., Brinkhuis, H., Williams, G.L., 2001. Midto late Eocene organicwalled dinoflagellate cysts from ODP Leg 171B, offshore Florida. In: Kroon, D., Norris, R.D., Klaus, A. (Eds.), Western North Atlantic Palaeogene and Cretaceous Palaeoceanography. Geological Society of London Special Publications, 183, pp. 225-251.

Wade, B.S., Kroon, D., 2002.Middle Eocene regional climate instability: evidence from the western North Atlantic. Geology 30, 1011-1014. Walker, J.C.G., Hays, P.B., Kasting, J.F., 1981. A negative feedback mechanism for the long term stabilization of Earth's surface temperature. J. Geophys. Res. 86, 9776-9782. http://dx.doi.org/10.1029/JC086iC10p09776.

Weber, M.E., 1998. Estimation of biogenic carbonate and opal by continuous nondestructive measurements in deep-sea sediments: application to the eastern Equatorial Pacific. Deep-Sea Res. I 45, 1955-1975.

Witkowski, J., Harwood, D.M., Chin, K., 2011. Taxonomic composition, paleoecology and biostratigraphy of Late Cretaceous diatoms from Devon Island, Nunavut, Canadian High Arctic. Cretac. Res. 32, 277300. $\quad$ http://dx.doi.org/10.1016/j.cretres.2010.12.009.

Witkowski, J., Bohaty, S.M., McCartney, K., Harwood, D.M., 2012. Enhanced siliceous plankton productivity in response to middle Eocene warming at Southern Ocean ODP Sites 748 and 749. Palaeogeogr. Palaeoclimatol. Palaeoecol. 326328, 78-94. http://dx.doi.org/10.1016/j.palaeo.2012.02.006.

Yool, A., Tyrrell, T., 2003. Role of diatoms in regulating the ocean's silicon cycle. Glob. Biogeochem. Cycles 17, 1103. http://dx.doi.org/10.1029/2002GB002018.

Zachos, J.C., Pagani, M., Sloan, L., Thomas, E., Billups, K., 2001. Trends, rhythms, and aberrations in global climate $65 \mathrm{Ma}$ to present. Science 292, 686-693.

Zachos, J.C., Dickens, G.R., Zeebe, R.E., 2008. An early Cenozoic perspective on greenhouse warming and carbon-cycle dynamics. Nature 451, 279$283 . \quad$ http://dx.doi.org/10.1038/nature06588. 